\title{
Changes imposed by pyrolysis, thermal gasification and incineration on composition and phosphorus fertilizer quality of municipal sewage sludge
}

Thomsen, Tobias Pape; Sárossy, Zsuzsa ; Ahrenfeldt, Jesper; Henriksen, Ulrik Birk; Jappe Frandsen, Flemming; Müller-Stöver, Dorette Sophie

Published in:

Journal of Environmental Management

Link to article, DOI:

10.1016/j.jenvman.2017.04.072

Publication date:

2017

Document Version

Peer reviewed version

Link back to DTU Orbit

Citation $(A P A)$ :

Thomsen, T. P., Sárossy, Z., Ahrenfeldt, J., Henriksen, U. B., Jappe Frandsen, F., \& Müller-Stöver, D. S. (2017). Changes imposed by pyrolysis, thermal gasification and incineration on composition and phosphorus fertilizer quality of municipal sewage sludge. Journal of Environmental Management, 198, 308-318.

https://doi.org/10.1016/j.jenvman.2017.04.072

\section{General rights}

Copyright and moral rights for the publications made accessible in the public portal are retained by the authors and/or other copyright owners and it is a condition of accessing publications that users recognise and abide by the legal requirements associated with these rights.

- Users may download and print one copy of any publication from the public portal for the purpose of private study or research.

- You may not further distribute the material or use it for any profit-making activity or commercial gain

- You may freely distribute the URL identifying the publication in the public portal 


\title{
Changes imposed by pyrolysis, thermal gasification and incineration on elemental composition and phosphorus fertilizer quality of municipal
} sewage sludge

\author{
Tobias Pape Thomsen ${ }^{* a},{ }^{a}$ Zsuzsa Sárossy ${ }^{a}$, Jesper Ahrenfeldt ${ }^{a}$, Ulrik Henriksen $^{a}$, Flemming J. Frandsen $^{a}$, \\ Dorette Sophie Müller-Stöver ${ }^{b}$ \\ ${ }^{a}$ Technical University of Denmark, Department of Chemical Engineering, DTU Risø Campus, Technical University of Denmark Building 313, \\ Frederiksborgvej 399, 4000 Roskilde, Denmark. ${ }^{*}$ Corresponding author (T. Thomsen), email: ttho@kt.dtu.dk \\ ${ }^{b}$ University of Copenhagen, Department of Plant and Environmental Sciences, Plant and Soil Science, Thorvaldsensvej 40, Frederiksberg, Denmark
}

\begin{abstract}
In this study, the solid residuals (ash and char) from incineration, gasification and pyrolysis of the same municipal sewage sludge sample were investigated to determine differences in heavy metal content and phosphorus $(P)$ plant availability. In addition, a process for post oxidation of the residuals from gasification and pyrolysis was developed and the oxidized materials were investigated as well. A detailed sequential extraction with full elemental characterization of the extracted pools as well as scanning electron microscopy with energy dispersive $\mathrm{X}$-ray spectroscopy were used to examine the mechanisms driving the observed differences in composition and $\mathrm{P}$ plant availability among the different residues. The compositional changes related mainly to the organic mass loss of the sludge during the thermal processes as well as to differences in the release of sulfur and cadmium. Especially thermal gasification was able to greatly reduce the cadmium content in the resulting ash. Post-oxidized slow pyrolysis char was found to be the substrate with the highest $P$ fertilizer value. It is suggested that the high $P$ fertilizer values in the best substrates are functions of several different mechanism including mineralization of organic $P$, oxidation of Fe-P compounds, volatilization and re-condensation of $\mathrm{P}$ species in crystalline surface structures and improvements in the association of $\mathrm{P}$ to especially magnesium and calcium.
\end{abstract}

Keywords: Sewage sludge, pyrolysis, gasification, incineration, incubation study, phosphorous fertilizer

\section{Introduction}

Municipal sewage sludge (MSS) is an inevitable byproduct from municipal wastewater treatment which can be considered as a valuable by-product or as a problematic waste, depending on local politics, available handling options, and the quality of the MSS (Fytili and Zabaniotou, 2008; Hukari et al., 2016; Kelessidis and Stasinakis, 2012). Usually, MSS contains significant amounts of nitrogen (N), phosphorus (P), organic matter and various micro nutrients. These valuable constituents make MSS in many regards a cheap fertilizer and soil enhancer (Linderholm et al., 2012). For this reason, composting or direct application of MSS on farm soil or in landscaping has been practiced intensively in the past (Fytili and Zabaniotou, 2008).

However, MSS can also contain significant amounts of emerging organic pollutants and xenobiotics (e.g. antibiotics, fragrances, UV-filters, antiseptics, micro plastics, phthalates, hormones etc.) as well as heavy metals and pathogens (Choban and Winkler, 2008; Igos et al., 2012; Krüger et al., 2014; Michael et al., 2013). In recent years, concerns related to the use of MSS on farm land have increased with new 
developments in the knowledge about the potential harmful effects of this practice related to food production and ground water quality (Fytili and Zabaniotou, 2008; Krüger et al., 2014). For this reason, incineration of MSS - either by dedicated mono-incineration or by co-firing in production of e.g. mineral insulation materials - has been growing into conventional practice in many countries (Krüger et al., 2014), and several EU member countries now have harder restrictions on MSS application than the current EUdirective (Kelessidis and Stasinakis, 2012).

The dilemma between recovery of MSS nutrients and the risks related to direct application in food production systems is further complicated by a growing political demand for increased P-recycling on the one hand, and the increased concentration of heavy metals and loss of $\mathrm{P}$ plant availability often associated with incineration on the other hand (Jakobsen and Willett, 1986; Krüger et al., 2014; Mattenberger et al., 2008; Nzihou and Stanmore, 2013; Ottosen et al., 2013). To meet this challenge, new ways to upgrade ash from MSS incineration or recirculate MSS-P directly are under development (Atienza-Martínez et al., 2014; Franz, 2008; Ottosen et al., 2016; Parés Viader et al., 2015; Vogel et al., 2013; Xu et al., 2012). An optimal solution for MSS handling would utilize the energy potential of the MSS, preserve $P$ and other nutrients in a plant-available form, reduce volume and weight, remove heavy metals, destroy pathogens and organic xenobiotics and be cheap and reliable.

Thermal conversion of MSS can comply with several of these requirements, but the benefits and drawbacks vary with the design of the thermal process. MSS can be thermally converted in processes involving pyrolysis, thermal gasification or incineration or various combinations hereof (Fytili and Zabaniotou, 2008; Manara and Zabaniotou, 2012; Nakakubo et al., 2012; Samolada and Zabaniotou, 2014). During pyrolysis of MSS, up to $80 \%$ of the energy potential can be recovered as energy products (oil or gas) while the rest remains in the solid residual (char) as a recalcitrant carbon matrix (Cao and Pawłowski, 2012). During incineration of MSS almost all energy potential is released and the energy potential of the solid residual (ash) is zero or practically zero (Krüger et al., 2014). Thermal gasification is positioned in between pyrolysis and incineration with respect to the degree of conversion and energy utilization. Thermal gasification of MSS can reach more than $90 \%$ thermal efficiency while it still leaves a minor part of total fuel energy content in the ash. However, the degree of conversion during thermal gasification of MSS varies substantially with the design of the process and the characteristics of the specific fuel (Judex et al., 2012; Mun et al., 2013; Samolada and Zabaniotou, 2014; Werle, 2015).

To our knowledge, there is no comprehensive study comparing pyrolysis, gasification and incineration of MSS with regard to changes in the ash composition and $P$ fertilizer quality compared to the original MSS sample. To investigate these differences, it is mandatory to convert sub-samples of the same MSS sample on all assessed thermal conversion platforms. In this way, robust correlations between the degree of conversion, the utilization of the energy potential, the heavy metal content and the $P$ fertilizer quality may be identified, and characteristics of the optimal thermal design may be determined.

A Cross Platform Sludge Experiment (CPSE) has been designed and executed in collaboration between two Danish universities and four Danish companies. The purpose of the CPSE study was to compare key fertilizer characteristics of ashes and chars produced by thermal conversion of sub-samples from a single large MSS sample on multiple thermal platforms and determine how the plant design and operation parameters affect these properties. The main focus of the study was to characterize and analyze changes in $P$ chemistry induced by the thermal conversion and relate these to changes in the P-fertilizer quality of the 
ash or char compared to the MSS fuel. The study aimed at acquiring new knowledge about the behavior of phosphorous as well as of selected heavy metals during thermal conversion of MSS. The study is the first of its kind, and the proposed method and results are expected to increase the odds of developing more optimal thermal MSS management platforms.

\section{Methods}

\subsection{The MSS sample}

MSS from the municipal wastewater treatment plant (WWTP) Bjergmarken Renseanlæg in Roskilde, Denmark, was used as fuel for all thermal fuel conversion experiments. The WWTP is a MechanicalBiological (active sludge loop)-Nitrification-Denitrification-Chemical cleaning facility (MBNDC) dimensioned for 125.000 person equivalents (PE), and usually treating wastewater corresponding to $92.000 \mathrm{PE}$. Iron chloride sulfate $\left(\mathrm{ClFeO}_{4} \mathrm{~S}\right)$ is used for chemical $\mathrm{P}$ removal and added before the active sludge cycle, while aluminum chloride $\left(\mathrm{AlCl}_{3}\right)$ is added in the clarifiers and used mainly to precipitate floating sludge and prevent filamentous bacteria in the cold season. All sludge goes through the active sludge cycle before it is digested anaerobically for three weeks in a thermophilic process. After digestion, the sludge is mechanically dewatered and dried. Sludge can be produced as de-watered MSS, dry MSS granules or dry MSS pellets. The drying is conducted in a BioCon drying and granulating unit (Krüger A/S, Denmark) using hot air at temperatures ranging from 100 to $175^{\circ} \mathrm{C}$ (Krüger, 2009). The complete MSS sample used for the CPSE study was produced during 6 consecutive days in March 2015. Day 1-3: Around $2 \mathrm{t}$ dry MSS pellets with $83.7 \pm 1.0$ wt\% dry matter and around $3 \mathrm{t}$ of dry MSS granules with $87.5 \pm 1.4 \mathrm{wt} \%$ dry matter; Day 4-6: 22.8 ton of dewatered MSS with $23.9 \pm 1.1 \mathrm{wt} \%$ dry matter for full scale incineration.

\subsection{The thermal conversion processes}

The thermal conversion processes of the CPSE study include 2 incineration processes, 2 pyrolysis processes and 2 gasification processes. All ashes, chars and MSS samples that were collected in the study are collectively referred to as the CPSE substrates. The processes are all described briefly below, while an overview is provided in Table 1.

\subsubsection{Fluid-bed incineration at $850^{\circ} \mathrm{C}$}

The experiment was conducted at Spildevandscenter Avedøre, Denmark in March 2015, in a monoincineration process conducted on a fluid-bed oven, with a maximum capacity around 6.5 tons of dewatered MSS per hour (at $77 \%$ moisture). The incineration occurs at bed temperatures around $8400^{\circ} \mathrm{C}$ and freeboard temperatures around $890^{\circ} \mathrm{C}$. The average particle retention time in the oven is around 5 seconds according to the oven operator and supplier (Prisum, 1999). After incineration, the ash particles are captured and cooled in an electrostatic filter ( $98 \mathrm{wt} \%$ of ash removed at $180-220^{\circ} \mathrm{C}$ ) and a bag house filter ( $2 \%$ of ash removed at $160^{\circ} \mathrm{C}$ ). The two ash fractions are transported to a storage silo and mixed. Three ash sub-samples of around $200 \mathrm{~kg}$ each were collected from the ash silo.

\subsubsection{Fixed bed incineration at $750^{\circ} \mathrm{C}$ and $850^{\circ} \mathrm{C}$}

The experiment was conducted in the laboratories of the Biomass Gasification Group (BGG) at DTU, Ris $\varnothing$ Campus near Roskilde, Denmark, in April and May 2015. Samples were pre-dried for 24 hours in hot air at $104{ }^{\circ} \mathrm{C}$. Two batches with around $0.5 \mathrm{~kg}$ dry MSS distributed in multiple thin layers of $1-2 \mathrm{~cm}$ were 
incinerated in an electrically heated oven of around $40 \mathrm{~L}$, supplied with $5 \mathrm{~L}$ air per minute. Maximum temperatures were 750 and $850^{\circ} \mathrm{C}$, maintained for 30 minutes, with heating and cooling rates of 10 ${ }^{\circ} \mathrm{C} / \mathrm{min}$. Around $200 \mathrm{~g}$ of ash was produced at each temperature.

\subsubsection{Two-Stage down draft gasification}

The experiment was carried out in April and May 2015 at BGG, Ris $\varnothing$ DTU, converting MSS pellets in a pilot scale TwoStage downdraft gasifier with a thermal capacity of $50 \mathrm{~kW}$. The plant is a simplified version of the VIKING gasifier (Ahrenfeldt et al., 2013a, 2006; Hansen et al., 2015; Henriksen et al., 2006) and the main differences relate to the reduced thermal capacity and scale as well as the absence of internal heat integration in the $50 \mathrm{~kW}$ unit. The internal temperature regimes and atmospheres are roughly comparable in the $50 \mathrm{~kW}$ TwoStage gasifier and the VIKING gasifier. However, the MSS gasification in the $50 \mathrm{~kW}$ unit was conducted with a regulation strategy to avoid maximum temperatures above $1000{ }^{\circ} \mathrm{C}$ which is not usually applied when gasifying wood. The high-end temperature in the char bed was up to $850^{\circ} \mathrm{C}$ during the CPSE experiment. Around $20 \mathrm{~kg}$ of ashes were collected for analysis.

\subsubsection{Low Temperature Circulating Fluidized Bed Gasification}

This experiment was carried out in April 2015 at BGG, Ris $\varnothing$ DTU, converting MSS granules on a pilot-scale Low Temperature Circulating Fluidized Bed gasifier (LT-CFB gasifier), (Ahrenfeldt et al., 2013b; Kuligowski et al., 2008; Narayan et al., 2016; Nguyen et al., 2013; Nielsen, 2007; Stoholm et al., 2007; Thomsen et al., 2015; Zwart et al., 2010) with a thermal capacity of $100 \mathrm{~kW}$. Ash for the CPSE study was extracted from the bed of the char reactor at temperatures typically around $730^{\circ} \mathrm{C}$. Sand was sieved off with a $0.6 \mathrm{~mm}$-steel mesh, and ash- and char particles with a diameter larger than $0.6 \mathrm{~mm}$ were recovered as bottom ashes. This fraction constituted around $25 \%$ of the total bed mass. Around $40 \mathrm{~kg}$ of bottom ashes were collected.

\subsubsection{Slow pyrolysis}

The experiments were conducted in April 2015 in the laboratories of BGG, Ris $\varnothing$ DTU, on dry MSS pellets as well as dry MSS granules. Samples were pre-dried for 24 hours at $104{ }^{\circ} \mathrm{C}$. Several batches of around $2 \mathrm{~kg}$ each were pyrolyzed in an electrically heated $3.5 \mathrm{~L}$ closed steel reactor with $\mathrm{N}_{2}$ sweep and gas outlet. Maximum pyrolysis temperature was $600{ }^{\circ} \mathrm{C}$ which was maintained for 2 hours with initial heating rates and subsequent cooling rates of approximately $6^{\circ} \mathrm{C} / \mathrm{min}$. An $\mathrm{N}_{2}$ flush at $5 \mathrm{~L} / \mathrm{min}$ was applied for the first 20 minutes, followed by $2 \mathrm{~L} / \mathrm{min}$ for the remaining treatment. The procedure is described in Thomsen et al 2015 (Thomsen et al., 2015). $10 \mathrm{~kg}$ of pyrolysis char were produced.

\subsubsection{Fast pyrolysis}

The experiment was conducted in April 2015 at Frichs A/S in Havndal in Jutland, Denmark, converting MSS pellets in an externally heated fast pyrolysis plant with a maximum thermal capacity of $1 \mathrm{MW}$. The practical capacity doing the experiment was around $300 \mathrm{~kW}$. The operation temperature set point was $850^{\circ} \mathrm{C}$, but inconsistencies with the feeding rate resulted in periods with temperatures as low as $540{ }^{\circ} \mathrm{C}$. The actual average temperature during the experiment is unknown. After initial grinding, the MSS was heated to max temperature within seconds. Hereafter, the particles were carried with the gas through the system before the char was separated out and conveyed into a wetted storage. Around $75 \mathrm{~kg}$ of wetted MSS char were collected and dried for 24 hours in hot air at $104^{\circ} \mathrm{C}$ before further analysis. 
Table 1: Overview of thermal processes in the Cross Platform Sludge Experiment project

\begin{tabular}{cccccc}
\hline Thermal process & Plant scale & Sample name & Atmosphere & $\begin{array}{c}\text { Max temp. } \\
\left({ }^{\circ} \mathrm{C}\right)\end{array}$ & Heating rate \\
\hline Fluid-bed incineration & Full scale & Fluid bed inc & Oxidizing & 850 & Very high \\
Fixed bed incineration & Lab. Scale & Fixed inc 750/850 & Oxidizing & $750 / 850$ & Very low \\
Two-Stage gasification & Pilot scale & TwoStage & Reducing & 850 & Low \\
LT-CFB gasification & Pilot scale & LT-CFB & Reducing & 750 & Very high \\
Slow pyrolysis & Lab. Scale & Slow pyr & Reducing & 600 & Very low \\
Fast pyrolysis & Demo scale & Fast pyr & Reducing & 750 & Very high \\
\hline
\end{tabular}

\subsubsection{Post oxidation}

To investigate the influence of an oxidizing atmosphere on the substrate characteristics in more detail, the following additional samples were prepared:

- Oxidized slow pyrolysis char (Slow pyr OX). The char from slow pyrolysis was re-heated at $6{ }^{\circ} \mathrm{C}$ /min to $600{ }^{\circ} \mathrm{C}$ in $\mathrm{N}_{2}$ atmosphere where after the $\mathrm{N}_{2}$ was replaced with air for 30 minutes. After 30 minutes, the atmosphere was changed back to $\mathrm{N}_{2}$, and the sample was cooled for 45-60 minutes.

- Oxidized LT-CFB ash (LT-CFB OX). The process was similar to the oxidation of the slow pyrolysis char except that the maximum oxidation temperature was $750^{\circ} \mathrm{C}$.

- Oxidized TwoStage gasification ashes. One sample (TwoStage OX) was produced in a process similar to the oxidation of the slow pyrolysis char but with an oxidation temperature of $850{ }^{\circ} \mathrm{C}$. A second sample (TwoStage OX2), was produced with an oxidizing atmosphere (air) during heating, 30 minutes at maximum temperature $\left(850^{\circ} \mathrm{C}\right)$, and subsequent cooling. $0 \times 2$ thereby received a more severe oxidation, but the same temperatures as the OX sample.

\subsection{Analytical procedures}

\subsubsection{Ash content}

Ash content of all CPSE substrates has been determined using the standard DS/EN 14775 (2009) (Ash content in biomass).

\subsubsection{Total $\mathrm{C}$ and total $\mathrm{N}$}

Total contents of $\mathrm{C}$ and $\mathrm{N}$ in the CPSE substrates were quantified at the Center for Permafrost, Department of Geosciences and Natural Resource Management, University of Copenhagen. The method involved Dumas combustion (1020 ㄷ) on an elemental analyzer (CE 1110, Thermo Electron, Milan, Italy).

\subsubsection{Main elements and heavy metals}

Substrates were digested in nitric acid and hydrogen peroxide at $240^{\circ} \mathrm{C}$ and 200 bars in a pressurized microwave oven for 15 minutes (Ultrawave, Milestone Inc., Italy). Hydrofluoric acid was added after digestion and cooling, and the samples were left standing overnight. The solutions were diluted before final analysis by inductively coupled plasma optical emission spectrometry (ICP-OES,Agilent 5100, Agilent Technologies, Santa Clara, USA)), using a procedure described by Hansen et al. (2009) (Hansen et al., 2009). 


\subsubsection{Soil incubation studies}

The soil used for the incubation study was a sandy loam soil with $16.5 \%$ clay that was collected in 2014 from the upper layer of a nutrient depletion trial on the University of Copenhagen's experimental research farm in Taastrup, Denmark. After collection, the soil was air-dried and passed through a $2 \mathrm{~mm}$ sieve. The soil had a pH of 5.2 and was mixed with quartz sand in a 50/50 w/w mixture for the incubation study.

All substrates used for the incubation study were pre-dried at $104{ }^{\circ} \mathrm{C}$, and ground until at least $90 \%$ of the total sample mass passed a $0.125 \mathrm{~mm}$ sieve and all particles were smaller than $0.25 \mathrm{~mm}$. The particle size management was conducted using a Mahlkönig Kenia Disc grinder (MAHLKÖNIG GmbH \& Co. KG, Hamburg, Germany), a FRITSCH Mortar Grinder Pulverisette 2 (Fritsch GmbH, Idar-Oberstein, Germany) and a Retsch Vibro Sieve with sieves $125 \mu \mathrm{m}$ and $250 \mu \mathrm{m}$ (Retsch GmbH, Haan, Germany).

Triplicates of $50 \mathrm{~g}$ soil/quartz sand mixture and CPSE substrate samples added at a rate of $80 \mathrm{mg} \mathrm{P} \mathrm{kg}{ }^{-1}$ soil/sand mix were prepared. The substrates were thoroughly mixed into the soil and mixtures were watered to $50 \%$ of the soil's water holding capacity $(\mathrm{WHC})$ with demineralized water. Substrate-free controls and samples with a mineral $\mathrm{P}$ reference $\left(\mathrm{KH}_{2} \mathrm{PO}_{4}\right)$ were included. After watering, the samples were incubated in a dark climate chamber (Memmert Celsius HPP749, Germany) for 2 weeks at $20.4 \pm 0.4{ }^{\circ} \mathrm{C}$ and $93 \pm 5 \% \mathrm{RH}$. Water content in all samples was monitored and adjusted daily.

\subsubsection{Anion-exchange resin (AER) strip extraction:}

After incubation, the samples were air dried and a sub-sample of $2 \mathrm{~g}$ was shaken for 16 hours with $30 \mathrm{ml}$ of $M Q$ and 2 anion exchange membrane (resin) strips (VWR international, DBH no 55164 2S, strip size $62 * 10$ $\mathrm{mm}$ ) in bicarbonate form. After the extraction, the strips were rinsed with water and shaken for 16 hours in new centrifuge tubes with $0.5 \mathrm{M} \mathrm{HCL}$. Extracts were stored at $4{ }^{\circ} \mathrm{C}$ until determination of the $\mathrm{P}$ eluded into the liquid on a Flow Injection Analyzer (FIAstart 5000, FOSS, Denmark).

\subsubsection{Sequential extraction}

MSS and ash samples were extracted with a series of solvents and the different fractions were analyzed with ICP-OES for elemental composition. The extraction procedure was based on the procedure of Tiessen and Moir (Moir and Tiessen, 2007) with the addition of ammonium acetate extraction based on the description of Kahiluoto et al (Kahiluoto et al., 2015). $0.5 \mathrm{~g}$ of sample was extracted with $30 \mathrm{~mL}$ of $\mathrm{MQ}, 0.5$ $\mathrm{M}$ ammonium acetate solution, $0.5 \mathrm{M} \mathrm{NaHCO}_{3}$ solution, $0.1 \mathrm{M} \mathrm{NaOH}$ solution and $1.0 \mathrm{M} \mathrm{HCl}$ solution, respectively. Each extraction was performed on a horizontal shaker overnight. After extraction, the sample was centrifuged and the supernatant filtered through a $0.45 \mu \mathrm{m}$ filter. The solids were subsequently extracted with the next solvent in the sequence while the filtrate was treated with $4 \mathrm{ml}$ of $\mathrm{cc}$. $\mathrm{HNO}_{3}$, autoclaved for 30 minutes at $120^{\circ} \mathrm{C}$ and filtered through a $0.45 \mu \mathrm{m}$ filter prior to analysis by ICP-OES (Varian 720-ES at DTU, Department of Civil Engineering). The analysis was done in duplicate.

\subsubsection{SEM-EDX}

Selected samples were analyzed with a scanning electron microscope (SEM) with energy dispersive X-ray spectroscopy (EDX). Samples were fixed on carbon tape and coated with gold prior to analysis. A FEl Inspect S SEM was used for image capturing. Point analysis (elemental point composition) was performed on selected substrates (3-5 particles, 15-30 points) with an EDX detector (Oxford Instruments). 


\section{Results and discussion}

\subsection{Composition of CPSE substrates}

Variations within the MSS sample were quantified and found to related almost exclusively to a $1 \%$ lower aluminum (Al) content in the de-watered MSS sample (results not shown).

\subsubsection{Content of total ash, $\mathrm{C}$ and $\mathrm{N}$ in CPSE substrates}

Most of the CPSE substrates contained only ash, or ash and small amounts of carbon (Table 2). However, in the char from slow and fast pyrolysis, there were considerable contents of $\mathrm{C}(22-23 \mathrm{wt} \%)$ and $\mathrm{N}(2 \%)$. The $\mathrm{N}$ content corresponded to a recovery of fuel $\mathrm{N}$ in the pyrolysis chars of 33-35\%. In the LT-CFB bottom ashes $7 \%$ of fuel $\mathrm{N}$ was recovered, but in all other samples almost all $\mathrm{N}$ was lost.

Table 2: Content of total ash, total $\mathrm{C}$ and total $\mathrm{N}$ of the sewage sludge fuel, chars and ashes

\begin{tabular}{lccccccc}
\hline Sample name & $\begin{array}{c}\text { Total ash } \\
\text { (wt\%, char) }\end{array}$ & $\begin{array}{c}\text { Total C } \\
\text { (wt\%, char) }\end{array}$ & $\begin{array}{c}\text { Total N } \\
\text { (wt\%, char) }\end{array}$ & $\begin{array}{c}\text { Total Sum } \\
\text { (wt\%, char) }\end{array}$ \\
\hline Dry sewage sludge & $42.3 \pm 1.2$ & $26.7 \pm 0.1$ & $3.7 \pm \pm 0.0$ & 72.8 \\
Slow pyr & $75.8 \pm 1.4$ & $22.6 \pm 1.3$ & $2.2 \pm \pm 0.0$ & 100.7 \\
Slow pyr OX & $94.9 \pm \pm 0.3$ & $5.6 \pm 0.2$ & $0.1 \pm \pm 0.0$ & 100.7 \\
Fast pyr & $68.2 \pm 0.3$ & $22.7 \pm 0.3$ & $2.1 \pm \pm 0.0$ & 93.0 \\
LT-CFB & $94.6 \pm 0.2$ & $7.2 \pm 0.0$ & $0.6 \pm 0.1$ & 102.4 \\
LT-CFB OX & $99.8 \pm 0.1$ & $0.1 \pm 0.0$ & $0.0 \pm 0.0$ & 99.9 \\
TwoStage & $92.1 \pm \pm 0.4$ & $5.8 \pm 0.2$ & $0.1 \pm \pm 0.0$ & 98.0 \\
TwoStage OX & $99.3 \pm 0.0$ & $0.3 \pm 0.1$ & $0.0 \pm 0.0$ & 99.6 \\
TwoStage OX2 & $100.0 \pm 0.0$ & $0.0 \pm 0.0$ & $0.0 \pm 0.0$ & 100.0 \\
Fluid bed inc 850 & $100.0 \pm 0.0$ & $0.5 \pm 0.0$ & $0.0 \pm 0.0$ & 100.5 \\
Fixed inc 750 & $100.0 \pm 0.0$ & $0.0 \pm 0.0$ & $0.0 \pm 0.0$ & 100.0 \\
Fixed inc 850 & $100.0 \pm 0.0$ & $0.0 \pm 0.0$ & $0.0 \pm 0.0$ & 100.0 \\
\hline
\end{tabular}

The low content of carbon in most samples shows that most of the energy potential in the MSS has been released in these processes. However, this is not the case for the pyrolysis processes. The degree of energy utilization in the slow pyrolysis process was estimated by assuming a chemical energy potential in the residual carbon in the char of $32.8 \mathrm{MJ} / \mathrm{kg}$ (Elert, 2016) and a Higher Heating Value of the dry MSS of 13.8 $\mathrm{MJ} / \mathrm{kg}$ DM (Thomsen et al., 2015). The recovery of mass in the slow pyrolysis process was $56 \%$, and the energy potential in the char was thus $30-35 \%$ of fuel energy, corresponding to release of $65-70 \%$ of the energy into the hot gas product. After post-oxidation of the slow pyrolysis char, around $95 \%$ of the energy potential in the MSS had been released. In general, post oxidation of chars and ash significantly reduced the carbon content and removed almost all traces of residual $\mathrm{N}$. In the fast pyrolysis char, there was an unidentified fraction of the composition which is likely to consist predominantly of $\mathrm{O}$ and $\mathrm{H}$. This indicates that there were unconverted organic fractions in the char sample. This could originate from an incomplete fast pyrolysis process, but by visual inspection of the char sample, at least part of the organic material was found to consist of small cereal straw particles (results not shown). The straw is expected to come from improperly cleaned parts of the pyrolysis unit and ash collection system. 


\subsubsection{Content of main elements and heavy metals in CPSE substrates}

Table 3: Contents of selected elements and heavy metals in CPSE substrates. All results on dry basis. Standard deviation 0-1 wt\% for main elements, 0-5 mg Cd/kg P, 0-200 mg Cr/kg P and 0-100 mg Ni/kg P. MSS: Municipal Sewage Sludge.

\begin{tabular}{lcccccccccc}
\hline & $\begin{array}{c}\mathrm{Al} \\
(\mathrm{wt} \%)\end{array}$ & $\begin{array}{c}\mathrm{Ca} \\
(\mathrm{wt} \%)\end{array}$ & $\begin{array}{c}\mathrm{Fe} \\
(\mathrm{wt} \%)\end{array}$ & $\begin{array}{c}\mathrm{K} \\
(\mathrm{wt} \%)\end{array}$ & $\begin{array}{c}\mathrm{Mg} \\
(\mathrm{wt} \%)\end{array}$ & $\begin{array}{c}\mathrm{P} \\
(\mathrm{wt} \%)\end{array}$ & $\begin{array}{c}\mathrm{S} \\
(\mathrm{wt} \%)\end{array}$ & $\begin{array}{c}\mathrm{Cd} \\
(\mathrm{mg} / \mathrm{kg} \mathrm{P})\end{array}$ & $\begin{array}{c}\mathrm{Cr} \\
(\mathrm{mg} / \mathrm{kg} \mathrm{P})\end{array}$ & $\begin{array}{c}\mathrm{Ni} \\
(\mathrm{mg} / \mathrm{kg} \mathrm{P})\end{array}$ \\
\hline Dry MSS & 2.1 & 5.1 & 3.0 & 0.5 & 0.6 & 4.0 & 0.8 & 61 & 1413 & 539 \\
Slow pyr & 4.5 & 10.2 & 5.3 & 1.1 & 1.2 & 8.0 & 0.8 & 53 & 1692 & 592 \\
Slow pyr OX & 6.7 & 12.8 & 7.8 & 1.3 & 1.6 & 9.1 & 0.9 & 55 & 2128 & 630 \\
Fast pyr & 2.2 & 5.3 & 4.7 & 1.5 & 0.9 & 7.5 & 0.7 & 44 & 1348 & 775 \\
LT-CFB & 5.8 & 13.0 & 7.1 & 1.6 & 1.7 & 11.0 & 1.0 & 15 & 1504 & 614 \\
LT-CFB OX & 7.2 & 13.6 & 8.1 & 1.6 & 1.7 & 9.5 & 0.8 & 10 & 2739 & 874 \\
TwoStage & 5.8 & 13.1 & 7.5 & 1.5 & 1.7 & 11.2 & 0.3 & 13 & 1483 & 1108 \\
TwoStage OX & 7.3 & 14.0 & 8.5 & 1.5 & 1.7 & 9.8 & 0.2 & 9 & 2313 & 1022 \\
TwoStage OX2 & 7.4 & 13.9 & 8.7 & 1.5 & 1.7 & 9.8 & 0.2 & 11 & 2697 & 1580 \\
Fluid bed inc 850 & 4.3 & 14.4 & 9.2 & 1.5 & 1.6 & 10.3 & 1.0 & 63 & 1232 & 1025 \\
Fixed inc 750 & 7.3 & 13.8 & 8.5 & 1.5 & 1.7 & 9.7 & 0.9 & 61 & 2155 & 672 \\
Fixed inc 850 & 7.5 & 13.8 & 8.5 & 1.5 & 1.7 & 9.9 & 0.8 & 61 & 2068 & 660 \\
\hline
\end{tabular}

The total P-contents in all chars and ashes were very high (Table 3), making them good potential P-fertilizer materials. The main differences in the composition related to variations in the organic content which dilutes the inorganic elements (Table 2). The significant deviation in especially Ca and Al contents in the fast pyrolysis char, confirms the previously noted observation of potential pollution of this sample by straw and/or straw char. The low Al-content in the Fluid bed inc 850 ash compared to the Fixed bed inc 850 ash supports the previously identified reduced Al-content in the de-watered MSS sample. This difference might be due to a decrease in the Al-dosing at the wastewater treatment plant as function of changes in the climate and/or sludge behavior when extracting the de-watered MSS sample for fluid bed incineration.

The results also show a significant decrease in S-content in the ashes from the TwoStage gasifier. Calculations of the S-content per unit of $P$ show a drop from $0.2 \mathrm{~g} / \mathrm{g} \mathrm{P}$ in the MSS to around $0.1 \mathrm{~g} / \mathrm{g} \mathrm{P}$ in ashes from incineration, LT-CFB gasification and in pyrolysis chars, down to $<0.02 \mathrm{~g} / \mathrm{g} P$ in ashes from TwoStage gasification. Releasing $S$ to the gas product is not beneficial, as $S$ is an important macro nutrient for plants and generally unwanted in boilers and exhaust emissions.

The thermal conversion significantly influenced the content of $\mathrm{Cd}, \mathrm{Cr}$ and Ni per unit of $\mathrm{P}$ (Table 3). No significant differences were observed in the concentration of $\mathrm{Zn}$ and $\mathrm{Pb}$ per unit of $\mathrm{P}$ (results not shown). The most evident changes are in the Cd-content per unit of $\mathrm{P}$, which is around $60 \mu \mathrm{g} / \mathrm{g} \mathrm{P}$ in the MSS sample and incineration ashes, $40-50 \mu \mathrm{g} / \mathrm{g} \mathrm{P}$ in pyrolysis chars, and around $10 \mu \mathrm{g} / \mathrm{g} \mathrm{P}$ in all ashes from thermal gasification. Cadmium is among the most toxic heavy metals, and often a limiting factor in the application of MSS in food production systems (Roberts, 2014; Zhang et al., 2008). High process temperatures are in general expected to facilitate a high Cd vaporization and release (Frandsen et al., 1994; Soria et al., 2013) which could explain the difference between the samples from pyrolysis and gasification. However, the $\mathrm{Cd}$ concentration was among the highest in the two incineration ashes produced at $850^{\circ} \mathrm{C}$. To avoid recondensation of released $\mathrm{Cd}$-species on entrained ash particles, it is proposed that hot separation of ashes is highly important in order to reduce the $\mathrm{Cd}$-content in the ash. The ashes from the fluid bed incineration 
were cooled before separation and this could be part of the explanation for the high Cd-content. However, ashes were separated at $850{ }^{\circ} \mathrm{C}$ in the Fixed inc ash samples, where no significant reduction is observed either. For this reason it is proposed that other factors than process temperature and hot ash separation must play an important role in regard to $\mathrm{Cd}$ reduction. Contents of especially $\mathrm{Cl}$ have previously been identified as key parameters in the release of $\mathrm{Cd}$ in reducing as well as oxidizing atmospheres, at temperatures from $400-1000{ }^{\circ} \mathrm{C}$. Elemental $\mathrm{S}$ has also been found to play an important role in Cd release and on the other hand, oxides of $\mathrm{Al}$ and silicon ( $\mathrm{Si}$ ) have been found to stabilize cadmium in solid form at temperatures above $830^{\circ} \mathrm{C}$ (Frandsen et al., 1994; Zhang et al., 2008, 2007). The content of $\mathrm{Cl}$ and Si and the related release behavior was not determined in this study. However, $\mathrm{Si}$ is expected to be present in all substrates in high concentrations, and the combination of high concentrations of $\mathrm{Si}$ - and Al-oxides and high temperatures may be part of the explanation for the apparent stabilization of $\mathrm{Cd}$ in the incineration ashes. Fewer oxides are present in the pyrolysis char and gasification ash due to a reducing atmosphere, and this could explain the increased rate of $\mathrm{Cd}$ release from these substrates. This would also explain why the post oxidation process had no positive impact on the Cd reduction.

\subsection{Incubation study}

Results from the anion-exchange resin (AER) strip extraction of $P$ from the incubated substrates are provided relative to the result of the mineral $P$ reference and the dry MSS reference, respectively.

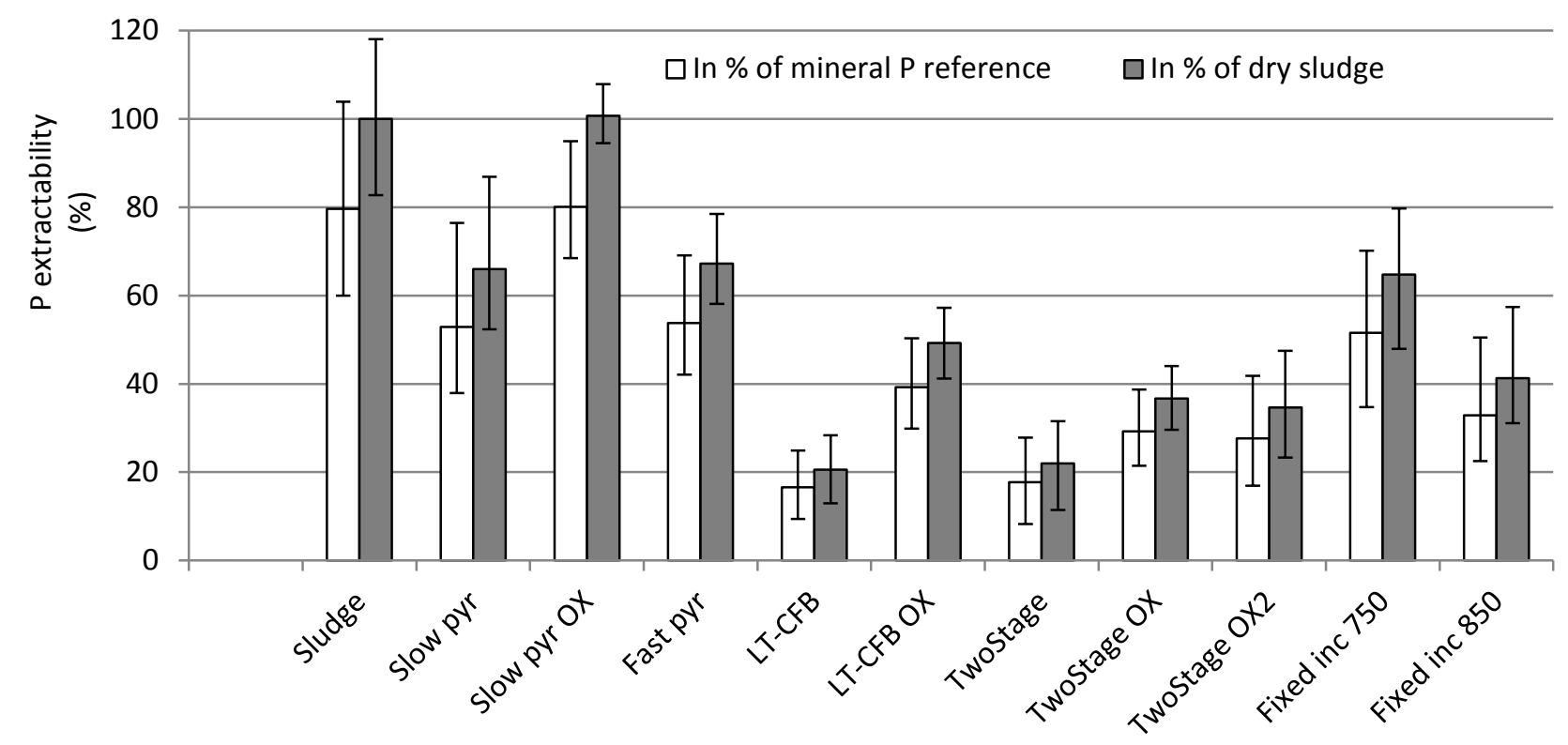

Figure 1: Anion-exchange resin strip P extraction of CPSE substrates after 2 weeks incubation. All results provided as extractability of $P$ in the given substrate in $\%$ of extractability of $P$ in the mineral $P$ reference and the dry sewage sludge sample. Values from the non-amended control soil are subtracted. Error bars represent standard deviations of the results.

The extractability of the $\mathrm{P}$ in the dry MSS was $80 \%$ of the extractability in the mineral $\mathrm{P}$ reference after two weeks of incubation (Figure 1). The P-fertilizer quality of sewage sludge has in some cases been found to be as good as mineral P-fertilizers but especially the use of Al-, Fe- and Ca-based precipitation chemicals can reduce the $P$ fertilizer quality (Fytili and Zabaniotou, 2008; Kahiluoto et al., 2015; Krogstad et al., 2005; Richardson et al., 2011; Singh and Agrawal, 2008; Suciu et al., 2015). An estimate of the Al- and Fe 
phosphate content of the CPSE MSS sample was made by combining data for the annual consumption of the precipitation chemicals $\mathrm{AlCl}_{3}$ and $\mathrm{CIFeO}_{4} \mathrm{~S}$ at the WWTP, the annual P load at the WWTP and assumed efficiencies of such precipitation chemicals: $50 \%$ for Fe-based chemicals and $75 \%$ for Al-based chemicals (Henze, 2006). With these data, around $10 \%$ of total MSS P can be expected to be on $\mathrm{FePO}_{4}$ form while around $16 \%$ would be present as $\mathrm{AlPO}_{4}$. Ca-P species like $\mathrm{Ca}_{2} \mathrm{HPO}_{4}(\mathrm{OH})_{2}$ and $\mathrm{Ca}_{5} \mathrm{OH}\left(\mathrm{PO}_{4}\right)_{3}$ as well as a fraction of organic $P$ is also expected to be present in the dry MSS (Beck et al., 2004; Krogstad et al., 2005). A quantification of organic $P$ has not been performed in this study, but in three MSS samples from Norwegian WWTP's undergoing comparable sludge treatment with anaerobic digestion, the organic $P$ content has previously been found to constitute $0.1-10 \%$ of total P (Krogstad et al., 2005). The pool of especially AI-P, Fe-P and organic-P compounds in the dry MSS as well as the influence of the thermal drying process is expected to be part of the reason why the P extractability in the MSS sample is reduced compared to the mineral $\mathrm{P}$ reference.

The two pyrolysis chars and the ash from fixed bed incineration at $750{ }^{\circ} \mathrm{C}$ performed best among the original CPSE substrates with AER-extractable P rates around $50 \%$ of the mineral P reference and $60 \%$ of the dry MSS. The Fixed inc 850 sample achieved extractability rates around $2 / 3$ of this level while the extractability of the $P$ in the gasification ashes and the fluid bed incineration ash was around $1 / 3$ of the best substrates. Results showed that the post-oxidation process substantially increased the $P$ availability in all cases. Post-oxidation was especially effective on LT-CFB ashes where the amount of AER-extractable P was more than doubled. There was no significant difference between the P extractability of the TwoStage OX and the TwoStage OX2 sample.

The following general trends were identified in the results from the incubation study: ${ }^{11}$ Pyrolysis generally performs better than gasification and incineration, ${ }^{2)}$ Post-oxidation of pyrolysis char and gasification ashes improves the $\mathrm{P}$ extractability, ${ }^{3)}$ Incineration generally outperforms gasification but oxidized gasification ashes perform as well as the best incineration ash, ${ }^{4)} \mathrm{AER}-\mathrm{P}$ extractability from incineration ashes produced at $750{ }^{\circ} \mathrm{C}$ are better than from those produced at $850{ }^{\circ} \mathrm{C},{ }^{5)}$ The fixed bed incineration ash performs better than fluid bed incineration at $850^{\circ} \mathrm{C}$. In general, increasing temperature seems to have a negative influence on the P plant availability. This has also been observed in other studies (Qian and Jiang, 2014). However, there are several deviations from this general trend and e.g. the differences between $P$ extractability of oxidized and non-oxidized samples that are produced at similar maximum temperatures. Therefore, other process parameters including heating rate, retention time and reaction atmosphere were also expected to play an important role with regard to $P$ availability in the residual product. During analysis and interpretation of the results from the incubation study, it should be kept in mind that results are from an incubation in a low-pH soil and could be different using alkaline soils as e.g. observed by Nanzer et al. (2014) (Nanzer et al., 2014).

\subsection{Sequential extraction (SE) with elemental analysis}

The focus during the SE analysis was investigation of P-related issues, but the complete set of main data from the work is provided as Supplementary Information in SI Table 1. 


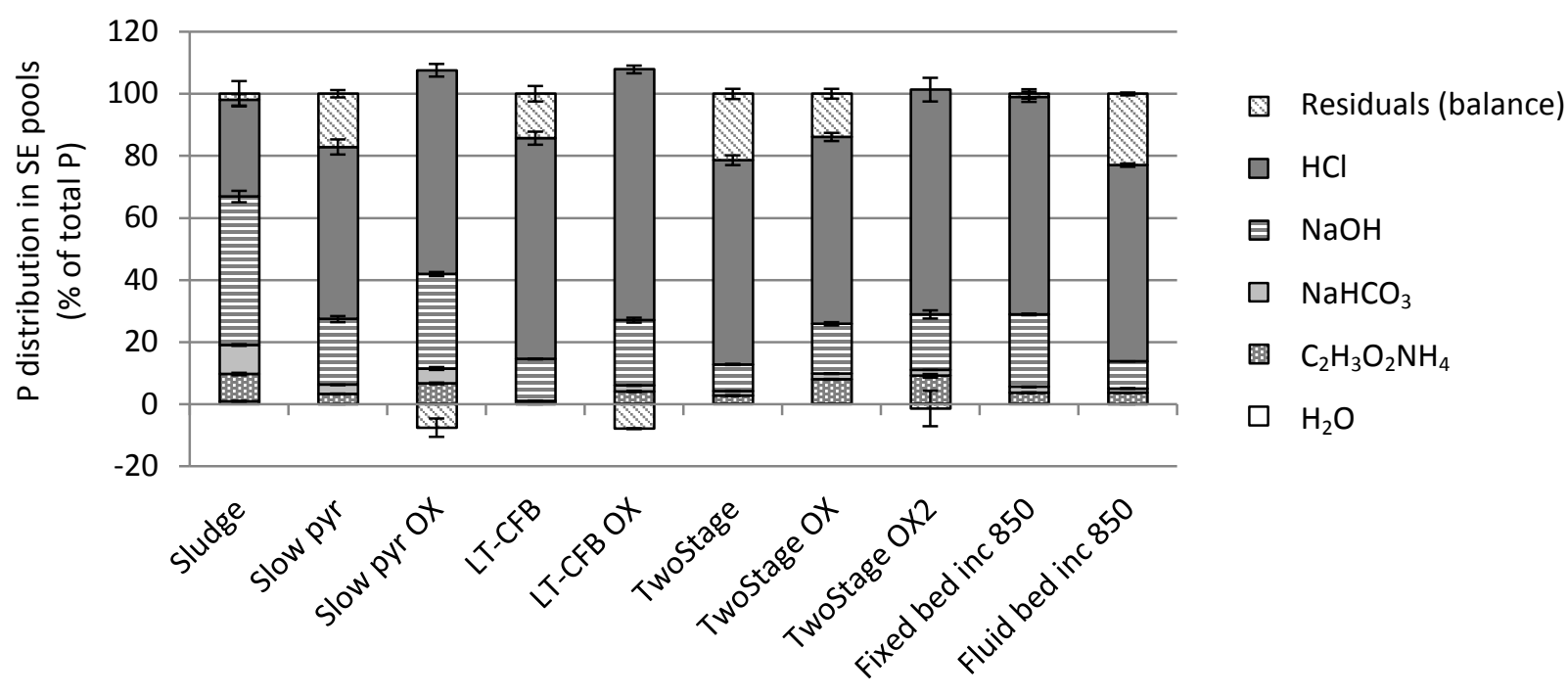

Figure 2: $P$ distribution in different pools from sequential extraction of CPSE substrates. All results are in \% of sample total $P$. Residual P content is calculated by balance. Error bars represent standard deviations of the results.

The results from the sequential extraction (Figure 2) show that most of the $P$ in the different substrates is soluble only in $\mathrm{HCl}$ or insoluble in the applied solvents (as "residuals", calculated by balance). This has also been observed in other studies (Fraser and Lum, 1983; Qian and Jiang, 2014). These fractions are usually expected to be only sparingly available, or unavailable, to plants (Moir and Tiessen, 2007; Qian and Jiang, 2014). This fractionation of the thermal residuals is in contrast to the fractionation of the MSS sample where the predominant fraction of $\mathrm{P}$ is in the $\mathrm{NaOH}$ pool. However, caution should be taken as previous work by Benzing et al (2005) showed that the $\mathrm{NaOH} \mathrm{P} \mathrm{pool} \mathrm{may} \mathrm{be} \mathrm{significantly} \mathrm{underestimated} \mathrm{and} \mathrm{the} \mathrm{HCl}$ $\mathrm{P}$ pool similarly overestimated in samples with high content of $\mathrm{CaCO}_{3}, \mathrm{Fe}-\mathrm{P}$ and $\mathrm{Al}-\mathrm{P}$ compounds (Benzing and Richardson, 2005). In general there is a risk of re-precipitation of solubilized elements by re-speciation in the solution. This is important to acknowledge as such effects can push elements from soluble pools to less soluble pools in the sequential extraction process. To identify such false results, elemental composition of each solid residual fraction should be determined for comparison. This has not been done in the present study, but based on the work of Lukkari et al (2007) the applied procedure is generally expected to provide reliable results for allocation of $P$ in mobile and immobile $P$ pools (Lukkari et al., 2007).

The transfer of $\mathrm{P}$ between $\mathrm{SE}$-pools follows the same trends for all thermal treatments. The main losses are from the $\mathrm{NaOH}$-pool and to a much lesser extent from the $\mathrm{H}_{2} \mathrm{O}, \mathrm{C}_{2} \mathrm{H}_{3} \mathrm{O}_{2} \mathrm{NH}_{4}, \mathrm{NaHCO}_{3}$-pools. As organic- $\mathrm{P}$ is often effectively recovered in alkaline solvents (Wang et al., 2013), a major part of it is expected to be recovered in the $\mathrm{NaOH}$-pool. Organic $\mathrm{P}$ is expected to mineralize during all the assessed thermal treatments, as the organic molecules to which the $\mathrm{P}$ is associated are either reduced to almost pure carbon structures, or completely oxidized. $\mathrm{P}$ removed from wastewater with $\mathrm{Fe}$ and $\mathrm{Al}$ based precipitation chemicals will reside in MSS as Al and Fe phosphates. Alongside certain Ca-P compounds, the Fe-P compounds are expected to reside in the $\mathrm{HCl}$ and residual SE P-pools, while Al phosphate is known to dissolve in $\mathrm{NaOH}$ at pH higher than 13 (Donatello and Cheeseman, 2013). However, the previously mentioned risk of underestimating the $\mathrm{NaOH} \mathrm{P} \mathrm{pool} \mathrm{in} \mathrm{Ca-rich} \mathrm{samples} \mathrm{also} \mathrm{includes} \mathrm{a} \mathrm{risk} \mathrm{of} \mathrm{severely}$ underestimating the $\mathrm{NaOH}$ Fe pool (Benzing and Richardson, 2005). It is thus expected that the large 
decease in the $\mathrm{NaOH}-\mathrm{P}$ pool during thermal conversion of MSS includes decomposition of organic matter and re-speciation of organic $\mathrm{P}$ and potentially also Al-P and Fe-P species.

The only pools gaining $\mathrm{P}$ during the thermal treatment are the $\mathrm{HCl}$-pools and the residual pool. This accounts for all substrates except for the fixed-bed incineration ash where the residual pool is unaffected. From the SI Table 4 it is noted that in addition to the fixed bed incineration ash, all other substrates with a long retention time in oxidizing atmosphere except for TwoStage OX have little or no $\mathrm{P}$ in the residual fraction. The same is the case with the MSS sample.

Using the data from Figure 1 and Figure 2, it was determined that there is an almost linear correlation $\left(R^{2}=0.84\right)$ between the incubation study results, given as $\mathrm{P}$ extractability in $\%$ of total $\mathrm{P}$ added on one side, and the accumulated fraction sum of $\mathrm{P}$ in the $\mathrm{SE}$-pools from extraction with $\mathrm{H}_{2} \mathrm{O}, \mathrm{C}_{2} \mathrm{H}_{3} \mathrm{O}_{2} \mathrm{NH}_{4}, \mathrm{NaHCO}_{3}$ and $\mathrm{NaOH}$ in \% of total $\mathrm{P}$ on the other (results not shown). If the $\mathrm{NaOH}$-pool is not included in the SE-P sum, the $\mathrm{R}^{2}$ value decreases to 0.54 , suggesting that at least a part of the $\mathrm{P}$ in the $\mathrm{NaOH}$ pool contributed to plant available $P$ after incubation.

\subsubsection{Transfer of main elements between SE pools induced by different thermal treatments}

To assess the transfer of elements between the SE pools induced by the thermal treatment it is important to have a solid understanding of the original $\mathrm{P}$ distribution and potential association of $\mathrm{P}$ in the MSS sample. Therefore, the allocation of key elements in the MSS sample among the SE pools is provided in Figure 3.

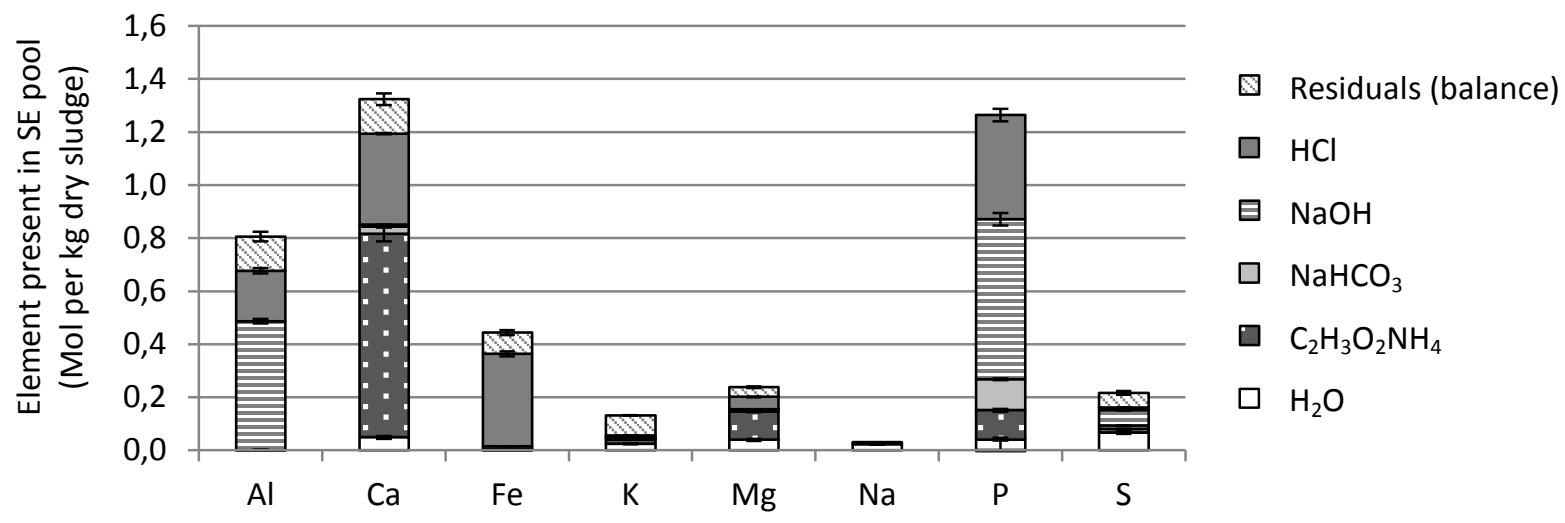

Figure 3: Sequential extraction of dry Municipal Sewage Sludge (MSS) from Bjergmarken WWTP in Roskilde, Denmark. Results in mole of element per kg dry matter. Residuals are calculated by balance. Error bars represent standard deviations of the results. $\mathrm{Na}$ only quantified in $\mathrm{SE}$ pools $\mathrm{H}_{2} \mathrm{O}$ and $\mathrm{C}_{2} \mathrm{H}_{3} \mathrm{O}_{2} \mathrm{NH}_{4}$ due to addition of $\mathrm{Na}$ in the third extraction.

The sequential extraction of the MSS sample clearly shows that most of the $\mathrm{P}$ was in the $\mathrm{NaOH}$ pool where the only other identified element was Al and a small amount of $\mathrm{S}$ meaning that the NaOH P pool most likely contained mainly Al-P and Organic P compounds. The second largest share of $\mathrm{P}$ was in the $\mathrm{HCl}$ pool that also contains $\mathrm{Al}, \mathrm{Ca}$ and $\mathrm{Fe}$. The quantity of $\mathrm{P}$ in the rather soluble $\mathrm{NaHCO}_{3}$ pool was accompanied by small amounts of $\mathrm{Ca}, \mathrm{K}$ and $\mathrm{S}$, but could also contain $\mathrm{Na}$ which was not measured in this pool. Finally, the highly soluble fraction of $\mathrm{P}$ in the $\mathrm{C}_{2} \mathrm{H}_{3} \mathrm{O}_{2} \mathrm{NH}_{4}$ and $\mathrm{H}_{2} \mathrm{O}$ pools was accompanied by large quantities of $\mathrm{Ca}, \mathrm{Mg}$ and $\mathrm{S}$ and a very small amount of Fe.

Figure 4 shows the net transfer of $\mathrm{Ca}, \mathrm{Al}, \mathrm{Fe}, \mathrm{Mg}, \mathrm{K}$ and $\mathrm{S}$ to and from the different $\mathrm{SE}$ pools during thermal conversion of MSS. The fixed-bed incineration was the only process where a significant positive net transfer 
of $\mathrm{Al}, \mathrm{Ca}, \mathrm{Fe}, \mathrm{Mg}$ and $\mathrm{K}$ relative to $\mathrm{P}$ was observed and this could indicate a $\mathrm{P}$ loss. Simple elemental balances were conducted for the slow pyrolysis process and the fixed bed incineration, indicating no $P$ loss during slow pyrolysis, but losses of up to $12 \%$ of total P during fixed bed incineration. These results support the identified pattern in the results in Figure 4. $\mathrm{P}$ losses were also observed in a study of Matinde et al. (2008) where incineration of MSS lead to release of $\mathrm{PO}$ and $\mathrm{PO}_{2}$ gas species at temperatures from $800{ }^{\circ} \mathrm{C}$ (Matinde et al., 2008). It is expected that the combination of high temperature and long retention time explains why there was a potentially high P-loss during the fixed bed incineration while no apparent indications of a P loss in the fluid bed incineration was observed.
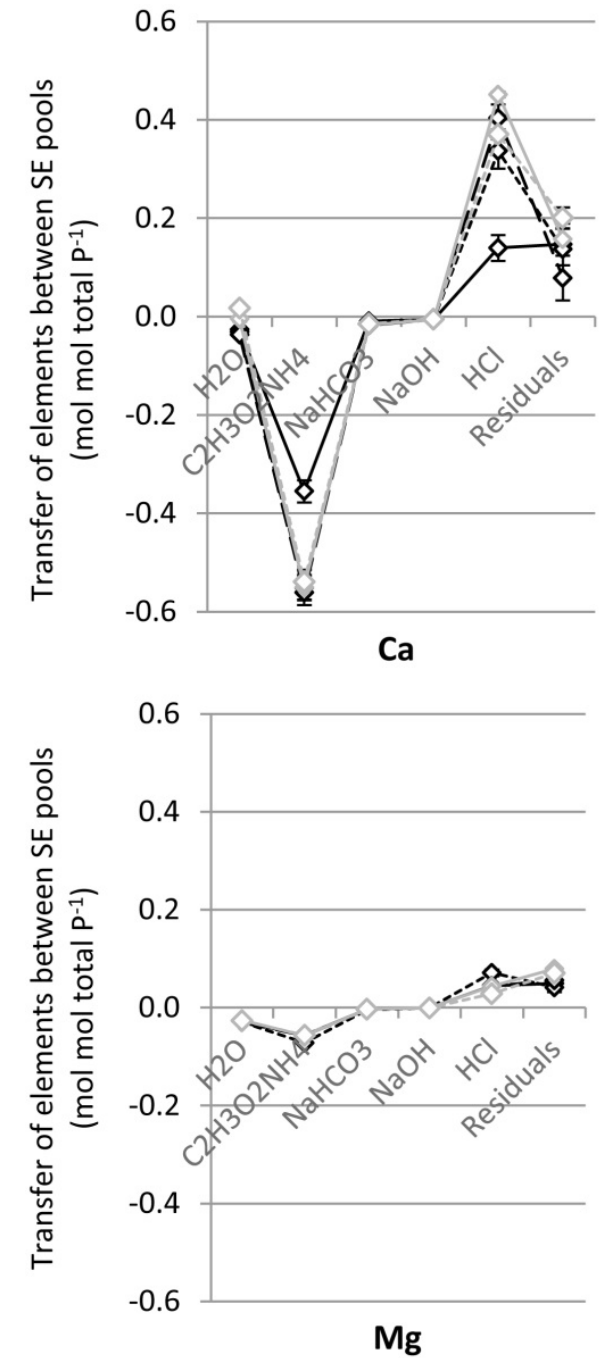

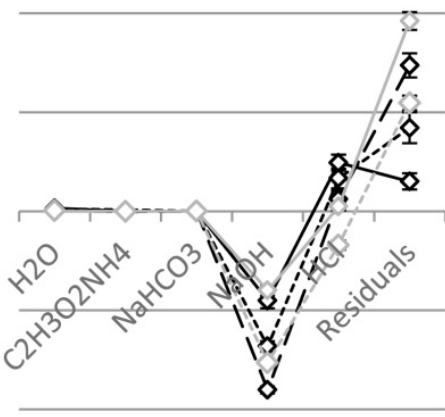

Al

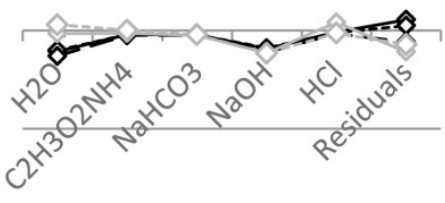

S

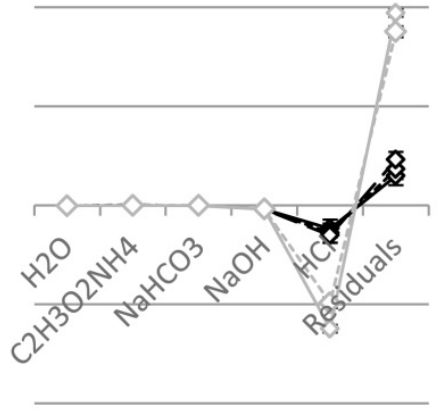

Fe

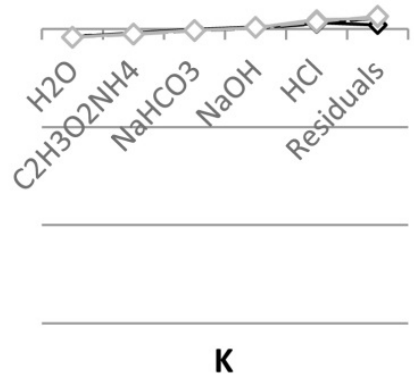

$\prec$ Slow pyr $\quad-\diamond--$ LT-CFB $\quad-\diamond-$ TwoStage $\prec-$ Fixed bed inc $--\diamond--$ Fluid bed inc

Figure 4: Movement of $\mathrm{Ca}, \mathrm{Al}, \mathrm{Fe}, \mathrm{Mg}, \mathrm{S}$ and $\mathrm{K}$ between $\mathrm{SE}$ pools due to different thermal sludge treatments. Charts show the molar change of a given element in a specific SE pool. Results are provided relative to the total $P$ content of the sample.

Donatello et al (2013) concluded that during incineration of MSS at $800-900{ }^{\circ} \mathrm{C}$, phosphate was mainly concentrated in the ash as whitlockite-type, tri-calcium phosphates $\left(\mathrm{Ca}_{3}\left(\mathrm{PO}_{4}\right)_{2}\right)($ Donatello and Cheeseman, 2013). The SE-results (Figure 2 and Figure 4) support this hypothesis, and it was observed how $P$ concentrated in the $\mathrm{HCl}$-pool and the residual fraction with $\mathrm{Ca}$ from the ammonium acetate pool as 
function of all primary thermal processes. Ca was transferred predominately from the ammonium acetate pool to the $\mathrm{HCl}$-pool and residual pool with a substantially lower rate of transfer in the slow pyrolysis char than in the other substrates. Al was being transferred from the $\mathrm{NaOH}$-pool to the $\mathrm{HCl}$ - and residual-pools. The allocation of Al between the $\mathrm{HCl}$ - and residual-pool seemed to be dependent on temperature, with a low temperature leading to high transfer to the $\mathrm{HCl}$-pool, and low movement to the residual-pool, and vice versa for high temperature processes. Potential Ca-P-Al species were also identified by XRD-analysis of the LT-CFB ash as well as the Fluid bed inc $850{ }^{\circ} \mathrm{C}$ ash in a related study (P. Viader et al., 2016). Both ashes were found to contain various calcium phosphates, including $\mathrm{Ca}_{9} \mathrm{Fe}\left(\mathrm{PO}_{4}\right)_{7}, \mathrm{Ca} 9 \mathrm{Al}\left(\mathrm{PO}_{4}\right)_{7}$ and/or $\mathrm{Ca} 7 \mathrm{Mg}\left(\mathrm{PO}_{4}\right)_{6}$. These findings are further supported by conclusions from a similar study by Atienza-Martínez et al (2014), identifying the same elements in MSS incineration ashes (Atienza-Martínez et al., 2014).

Transfer of Fe occurred mainly from the $\mathrm{HCl}$-fraction to the residual fraction, and the level of transfer was many times higher in the incineration processes than during pyrolysis and gasification. This could relate to reaction and oxidation of Fe phosphates. As Fe (III) phosphate $\left(\mathrm{FePO}_{4}\right)$ melts around $250^{\circ} \mathrm{C}$, it can be expected to participate in reactions during all CPSE thermal treatments. During high temperature oxidation, $\mathrm{FePO}_{4}$ is oxidized while forming acid-insoluble haematite, and acid-soluble phosphates. The formation of haematite is favored by higher temperatures and oxygen levels (Atienza-Martínez et al., 2014). This fits well to the observed pattern, and it is expected that the $\mathrm{HCl}$-pool Fe phosphates in the MSS were oxidized during incineration to new $\mathrm{HCl}$-pool phosphates (predominately Ca phosphates) and residual-pool Fe oxides (haematite, $\mathrm{Fe}_{2} \mathrm{O}_{3}$ ). In the study by Viader et al (2016), ash from the fluid-bed incineration, but not the LTCFB gasification, contained hematite, supporting the proposed Fe transfer pattern (P. Viader et al., 2016).

\subsubsection{Influence of post-oxidation of char and ash substrates on P-chemistry}

The general trend observed during post oxidation was the opposite of the general trend observed during the original thermal treatments. Post oxidation increased the share of $\mathrm{P}$ in the $\mathrm{H}_{2} \mathrm{O}, \mathrm{C}_{2} \mathrm{H}_{3} \mathrm{O}_{2} \mathrm{NH}_{4}, \mathrm{NaHCO}_{3}$ and $\mathrm{NaOH}$ pools compared to the non-oxidized materials (Figure 2) which was in line with the increased $\mathrm{P}$ availability observed in the soil incubation study (Figure 1). The post-oxidation increased the HCl P-pool in three of four oxidized samples while the residual SE-pool was completely removed in three of four oxidized samples, and reduced substantially in the fourth.

$P$ and $\mathrm{Al}$ are the elements which increased the most in the soluble SE-pools $\left(\mathrm{H}_{2} \mathrm{O}, \mathrm{C}_{2} \mathrm{H}_{3} \mathrm{O}_{2} \mathrm{NH}_{4}, \mathrm{NaHCO}_{3}\right.$ and $\mathrm{NaOH}$ ) during the post-oxidation process (Figure 2 and Figure 5). However, also $\mathrm{Mg}$ seemed to follow the transfer of $\mathrm{P}$ and $\mathrm{Al}$ in all samples. In several cases, the net movement of specific elements was positive, possibly due to a loss of $\mathrm{P}$ during the post oxidation process as expected based on the experiences of Matinde et al (2008) (Matinde et al., 2008). This was supported by simple elemental balances of the post oxidation processes, and it was found that around $10 \%$ of $\mathrm{P}$ is lost during post-oxidation, regardless of the process conditions (temperature and atmosphere during heating).

The transfer of $\mathrm{P}$ from the residual-pool was accompanied by transfers of $\mathrm{Ca}, \mathrm{Mg}$ and $\mathrm{S}$. The magnitude of the $\mathrm{Mg}$ and $\mathrm{Ca}$ transferred to the ammonium actetate-extractable pool correlated well with the amount of $\mathrm{P}$ on a 1:1 basis, where a majority of Ca was transferred in the low temperature treatments and a majority of $\mathrm{Mg}$ was transferred in the high temperature treatments. In a previous study, the formation of $\mathrm{Mg}-\mathrm{P}$ species, including farringtonite $\left(\mathrm{Mg}_{3}\left(\mathrm{PO}_{4}\right)_{2}\right)$ formed at temperatures around $750^{\circ} \mathrm{C}$, and, stanfieldite $\left(\mathrm{Ca}_{4} \mathrm{Mg}_{5}\left(\mathrm{PO}_{4}\right)_{6}\right)$, formed at temperatures around $850{ }^{\circ} \mathrm{C}$, was found to be a potential driver for increased bio-availability of thermochemically treated MSS ashes (Adam et al., 2009). Based on the movement of Ca 
and $\mathrm{P}$ to the acetate-pool, it is expected that the post-oxidation in some cases facilitated a formation of acid soluble $\mathrm{CaCO}_{3}-\mathrm{P}$ compounds (Wang et al., 2013). The only large transfer to the $\mathrm{NaOH}$-pool in addition to $\mathrm{P}$ was $\mathrm{Al}$, and across all treatments the magnitude of the movement corresponded well with $\mathrm{P}$ on a 1:1 basis. The $\mathrm{P}$-increase in the $\mathrm{HCl}$ pool was followed by a Ca-increase in the remaining substrates on a 1:1 basis, except for the TwoStage OX where the $\mathrm{HCl}$ P-pool was not increased. The migration of Fe from the $\mathrm{HCl}$-pool without accompanying P-losses indicates that Fe phosphates were oxidized and the new phosphates formed remained largely in the $\mathrm{HCl}$-pool. The level of Fe transfer followed the temperature regime of the oxidation processes as expected since the oxidation of Fe phosphates and subsequent formation of haematite is favored by high temperature and oxygen levels (Atienza-Martínez et al., 2014).
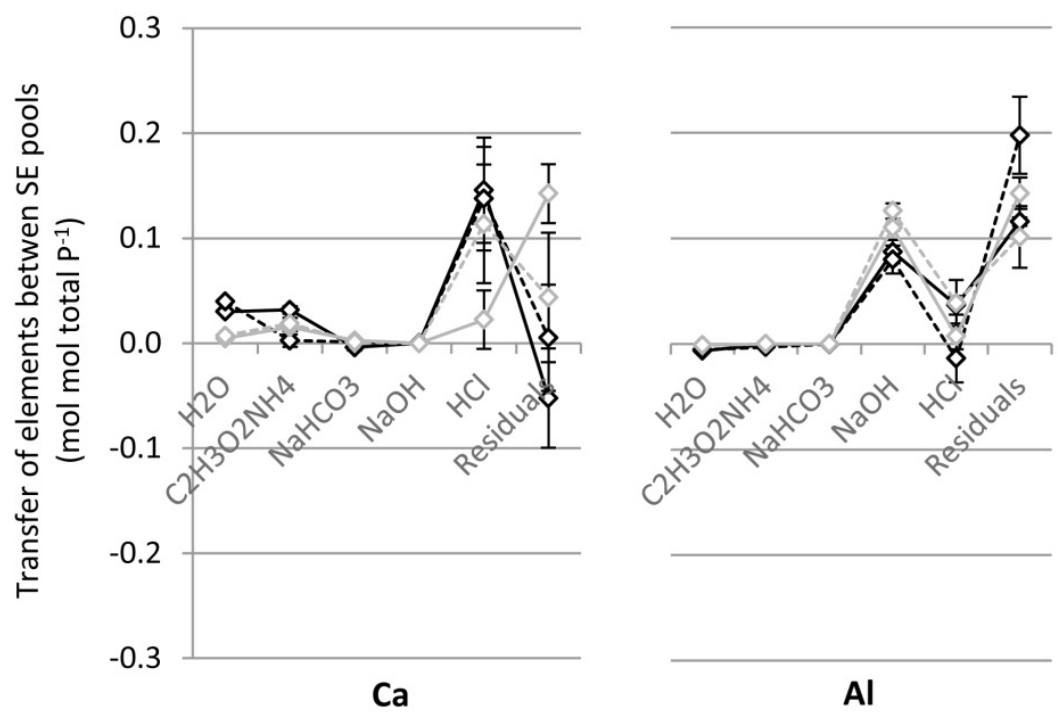

Al

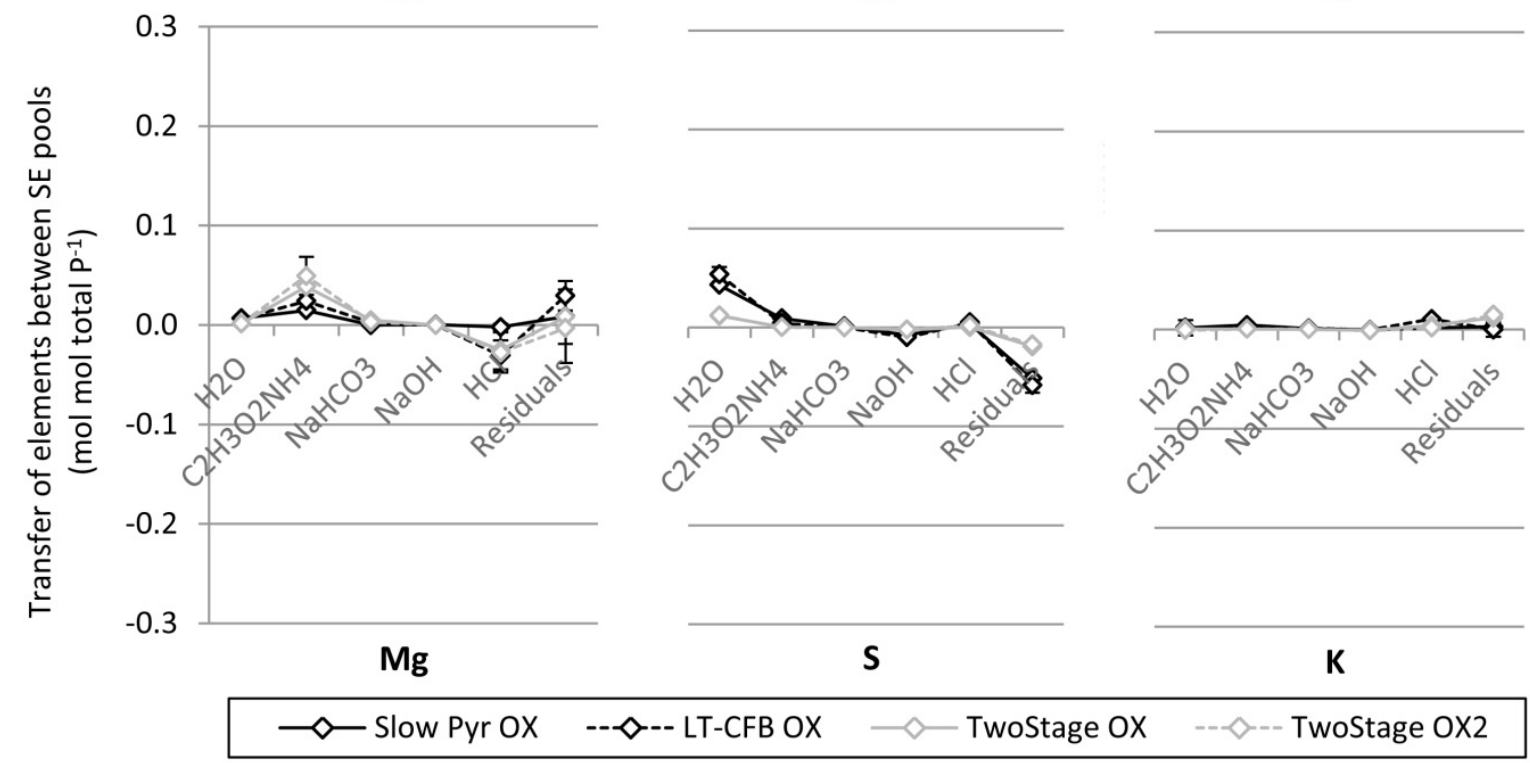

Figure 5: Net movement of $\mathrm{Ca}, \mathrm{Al}, \mathrm{Fe}, \mathrm{Mg}, \mathrm{S}$ and $\mathrm{K}$ between $\mathrm{SE}$ pools due to post-oxidation of char and ash substrates

\subsection{SEM}

SEM point composition analysis was performed on the following CPSE-substrates: Dry MSS, Slow pyr + Slow pyr OX, LT-CFB + LT-CFB OX and Fluid bed inc 850 with a focus of the chemical investigation on P, Al, Ca, Fe and Mg. Results are enclosed in the Supplementary Information (SI), SI Figure 1. 
From the SEM-EDS point analysis, it is evident that there was a very strong correlation between location of $\mathrm{P}$ and $\mathrm{Ca}$ in the dry MSS. The potential P-Ca ratio in the MSS was $0.9-1.2$ if $26 \%$ of the P content is subtracted due to potential capture by Fe and Al based precipitation chemicals as previously discussed. In a previous study with SEM-EDXS based point analysis of Fe and Al precipitated MSS, it was found that brushite $\left(\mathrm{CaHPO}_{2} \cdot 2 \mathrm{H}_{2} \mathrm{O}\right)$ was present in large quantities in samples, with $\mathrm{P} / \mathrm{Ca}$ ratios around or just below 1 (Huang et al., 2007). The presence of large quantities of brushite could explain the relatively high P fertilizer value of the MSS sample (Anderson et al., 2014).

From MSS to fluid-bed incineration ash, the correlations between $\mathrm{P}, \mathrm{Ca}$ and Fe were distorted, while a more significant correlation between $\mathrm{P}$ and $\mathrm{Mg}$ was developed. The highly scattered Fe pattern could be an indication of partial oxidation of the pool of Fe phosphates with the related formation of haematite and a concentration of $\mathrm{P}$ in the ash in whitlockite type, tri-calcium phosphates $\left(\mathrm{Ca}_{3}\left(\mathrm{PO}_{4}\right)_{2}\right)($ Donatello and Cheeseman, 2013). This could explain the increased $\mathrm{Ca} / \mathrm{P}$-ratio on several of the assessed points.

In the slow pyrolysis char and oxidized slow pyrolysis char, all correlations existing in the MSS were distorted, and no new strong correlations established. It is hypothesized that the low process temperatures, combined with the abundant carbon matrix in the pyrolysis char and the relatively short retention time in the oxidation process could have inhibited the achievement of chemical equilibrium and that this could be part of the explanation for the high scattering of P-relations in these substrates. This assumption is supported by the relatively high $\mathrm{N}$ content in the slow pyrolysis char as well as the carbon content still persisting in the sample after the oxidation process (Table 2). Additional post-oxidation of this type of substrate could be attempted to develop a better defined chemical structure and perhaps increase P plant availability additionally.

In the LT-CFB sample, the strong correlation of $\mathrm{P}$ to $\mathrm{Ca}$ was disrupted and an alignment of $\mathrm{P}$ and $\mathrm{Al}$ was initiated. The P-Fe pattern of the MSS was maintained, while the improved correlation between $\mathrm{P}$ and $\mathrm{Mg}$ observed in the fluid-bed ash was also found in the LT-CFB ash. In the oxidized LT-CFB ash, there was a remarkably strong correlation of $\mathrm{P}$ to $\mathrm{Ca}, \mathrm{Fe}, \mathrm{Al}$ and $\mathrm{Mg}$. The significance of the compositional patterns indicates a high level of crystallinity and chemical equilibrium in this sample. The previously suggested widespread presence of various calcium phosphates (e.g. $\mathrm{Ca} 9 \mathrm{Fe}\left(\mathrm{PO}_{4}\right)_{7}, \mathrm{Ca} 9 \mathrm{Al}\left(\mathrm{PO}_{4}\right)_{7}$ and $\left.\mathrm{Ca}_{18} \mathrm{Mg}_{2} \mathrm{H}_{2}\left(\mathrm{PO}_{4}\right)_{14}\right)$ (Atienza-Martínez et al., 2014; P. Viader et al., 2016) is supported by the high level of correlation between $\mathrm{P}, \mathrm{Ca}, \mathrm{Fe}, \mathrm{Al}$ and $\mathrm{Mg}$ in the results of the SEM-EDS analysis of the oxidized LT-CFB ash sample.

The SEM images of the different substrates (Figure 6) did not reveal obvious differences in the deep porosity of the different substrates. However, the images clearly show a characteristic surface change in the post oxidized samples (Figure $6 \mathrm{D}$ and $F$ ) where the structure of the original particle is surrounded by a highly porous, bright, crystalline structure. This structure was only found on the post-oxidized samples and not on the incineration ash. With the porosity and exposed position, this structure could play an important role related to plant availability of nutrients. The developed surface structure was most profound on the oxidized LT-CFB ash and it is expected that the development of this structure is related to the strong correlations between $\mathrm{P}, \mathrm{Ca}, \mathrm{Mg}$, Fe and $\mathrm{Al}$ (SI Figure 1). 

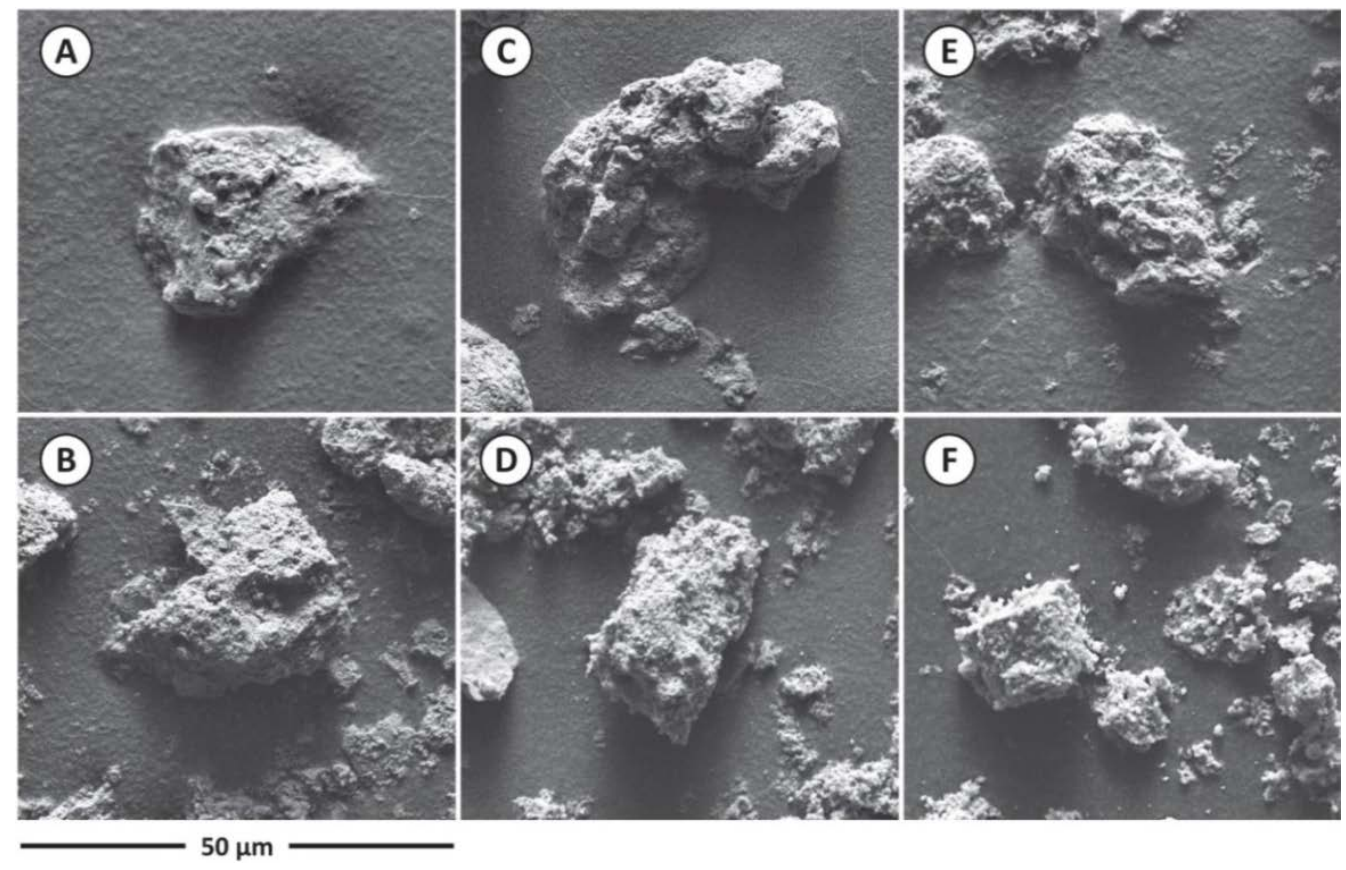

Figure 6: SEM pictures of selected CPSE substrates. A) Dry MSS B) Fluid bed incineration ash C) Slow pyrolysis char D) Oxidized slow pyrolysis char E) LT-CFB ash F) Oxidized LT-CFB ash

\section{Summary and conclusion}

Conversion of Municipal Sewage Sludge (MSS) in different thermal processes (incineration, pyrolysis or gasification) yielded solid residuals (ashes and chars) with significant differences in their composition and phosphorus $(P)$ fertilizer values. Even within a single category of thermal processes, differences in the design and process conditions yielded materials with very different $P$ fertilizer qualities. The most characteristic example of such differences within a group of substrates were observed between the ashes from two different types of sewage sludge incineration: Fluid bed incineration at $850{ }^{\circ} \mathrm{C}$ with short retention times and ashes from fixed bed incineration at $750{ }^{\circ} \mathrm{C}$ with much longer retention time. The fluid bed incineration ash was among the substrates with the lowest amount of Anion Exchange Resin (AER) extractable $P$ while the ashes from fixed bed incineration at reduced temperature were among the substrates with the highest amount of AER extractable P. Based on the findings of the study, it is clear that in regard to $P$ fertilizer value the performance of ashes from thermal conversion of MSS cannot be generalized just by the category of the thermal process.

Some of the most pronounced effects that the different thermal treatments had on the composition and fertilizer quality of the residual ashes and chars are provided in Table 4 and Table 5.

Pyrolysis followed by post-oxidation yielded the best P plant availability in the solid residuals. This combination also released the full energy potential in the MSS. Pyrolysis without post-oxidation had a lower $\mathrm{P}$ fertilizer value and around $30 \%$ of the MSS energy potential remained in the char. Incineration with high air ratios and a long retention time also proved to be a feasible way to produce an ash with high $P$ plant availability. However, the high $P$ fertilizer value of the ashes from fixed bed incineration and postoxidation seem to come at the expense of a significant $P$ loss. Based on the investigation of the surface of the post-oxidized substrates, it is suggested that increased $P$ fertilizer quality and loss of $P$ can be related to 
volatilization and re-condensation of $\mathrm{P}$ species. Post oxidation and fixed bed incineration processes are also proposed to increase $P$ fertilizer value by oxidation of Fe-P compounds and other sparingly soluble $P$ species as well as by a generally more beneficial association of $\mathrm{P}$ to especially $\mathrm{Mg}, \mathrm{S}$ and $\mathrm{Ca}$.

Based on the current study it is expected that the fertilizer value of residues from thermal conversion of MSS can be optimized even further. An initial reducing atmosphere will lead to release of cadmium, an effect being higher in gasification processes than during pyrolysis only. During incineration and postoxidation, $\mathrm{Cd}$ even seemed to be stabilized at the assessed temperatures. The optimal conditions for $\mathrm{Cd}$ release should be determined, including detailed investigations of the fate of other heavy metals. The $P$ fertilizer value increased after post-oxidation in all cases, but an additional optimization potential may still be present. It should in this regard be investigated which post-oxidation process conditions that enhance $P$ volatilization and how losses of $P$ in this process can be reduced. Finally, the results of the study should be validated and challenged by similar studies using different sludge samples (composition, particle size distribution), new thermal conversion processes, alternative soil available $P$ tests, soil types with different characteristics, and by growth experiments with various crops.

Table 4: Overview of identified positive changes and effects induced by different thermal treatments

\begin{tabular}{|c|c|c|}
\hline Change induced & Effect & Thermal Technology \\
\hline Content of ash $+\mathrm{C}+\mathrm{N}=100 \%$ & $\begin{array}{l}\text { Sludge purified, reduced risk, } \\
\text { Organic xenobiotics destroyed, }\end{array}$ & All technologies except fast pyrolysis \\
\hline Energy potential in sludge utilized & $\begin{array}{l}\text { Improved greenhouse gas balance } \\
\text { of the process and system }\end{array}$ & $\begin{array}{l}\text { Up to } 70 \% \text { in pyrolysis and close to } \\
100 \% \text { in all other cases }\end{array}$ \\
\hline Cd released & Reduced Cd/P content & Mainly Gasification but also pyrolysis \\
\hline Mineralization of organic $P$ & Could increase $P$ fertilizer value & All technologies \\
\hline Oxidation of $\mathrm{FePO}_{4}$ & Could increase $P$ fertilizer value & Incineration and post-oxidation \\
\hline $\begin{array}{l}\text { Oxidation of P-species in residual SE } \\
\text { fraction }\end{array}$ & Could increase $P$ fertilizer value & $\begin{array}{l}\text { Fixed bed incineration and post- } \\
\text { oxidation }\end{array}$ \\
\hline Association of $\mathrm{P}$ to $\mathrm{Mg}, \mathrm{S}$ and $\mathrm{Ca}$ & Could increase $P$ fertilizer value & Post-oxidation process \\
\hline Volatilization of $\mathrm{P}$ & Could increase $P$ fertilizer value & $\begin{array}{l}\text { Fixed bed incineration and post- } \\
\text { oxidation }\end{array}$ \\
\hline Changes in particle surface structure & Could increase $P$ fertilizer value & Post-oxidation process \\
\hline
\end{tabular}

Table 5: Overview of identified negative changes and effects induced by different thermal treatments

\begin{tabular}{|c|c|c|}
\hline Change induced & Effect & Thermal Technology \\
\hline Loss of $N$ & Reduced $\mathrm{N}$ fertilization & All technologies \\
\hline Loss of S & Reduced S fertilizer effect & Mainly TwoStage gasification \\
\hline Volatilization of $P$ & Loss of $\mathrm{P}$ & $\begin{array}{l}\text { Fixed bed Incineration and post } \\
\text { oxidation }\end{array}$ \\
\hline Cd re-condensation in ash collection & Increase Cd/P content & Cold ash-gas separation systems \\
\hline $\begin{array}{l}\text { Stabilization of Cd-species with } \\
\text { Al- and Si oxides }\end{array}$ & Prevent $\mathrm{Cd}$ release & $\begin{array}{l}\text { Incineration and post-oxidation at } \\
\text { high temperatures. }\end{array}$ \\
\hline $\begin{array}{l}\text { Concentration of } \mathrm{P} \text { in whitlockite- } \\
\text { type, tri-calcium phosphates }\end{array}$ & Could reduce $P$ fertilizer value & High temp. processes $800-900^{\circ} \mathrm{C}$ \\
\hline Increased residual SE pool & Could reduce $P$ fertilizer value & $\begin{array}{l}\text { All technologies except fixed bed } \\
\text { incineration and post-oxidation }\end{array}$ \\
\hline
\end{tabular}




\section{Acknowledgements}

The authors would like to thank everyone who contributed with practical, experimental and analytical work to this study. A special thanks to Hanne Wojtaszewski from DTU KT, Raimon Parés Viader, Pernille Erland Jensen and Ebba Schnell from DTU BYG, Berit Wenzell from DTU CEN, Lene Vigh and Lena Byrgesen from KU PLEN, Per Ambus from KU IGN, Peder Stoholm from DFBT, DONG Energy, Jørgen Krabbe and the technical staff from Frichs, Thomas Hvass, René Jacobsen and all the Torbens at Bjergmarken Renseanlæg \& FORS, Torben Pedersen and Dines Thornberg from BIOFOS \& the sludge incineration plant at Spildevandscenter Avedøre and Camilla Nygaard at Radiometer Medical. Finally, the authors would like to thank the Danish Energy Agency for financing the study via the EUDP program.

\section{Bibliography}

Adam, C., Peplinski, B., Michaelis, M., Kley, G., Simon, F.G., 2009. Thermochemical treatment of sewage sludge ashes for phosphorus recovery. Waste Manag. 29, 1122-1128.

doi:10.1016/j.wasman.2008.09.011

Ahrenfeldt, J., Egsgaard, H., Stelte, W., Thomsen, T., Henriksen, U.B., 2013a. The influence of partial oxidation mechanisms on tar destruction in TwoStage biomass gasification. Fuel 112, 662-680. doi:10.1016/j.fuel.2012.09.048

Ahrenfeldt, J., Henriksen, U., Jensen, T.K., Gøbel, B., Wiese, L., Kather, A., Egsgaard, H., 2006. Validation of a Continuous Combined Heat and Power (CHP) Operation of a Two-Stage Biomass Gasifier. Energy \& Fuels 20, 2672-2680. doi:10.1021/ef0503616

Ahrenfeldt, J., Thomsen, T.P., Henriksen, U., Clausen, L.R., 2013b. Biomass gasification cogeneration - A review of state of the art technology and near future perspectives. Appl. Therm. Eng. 50, 1407-1417. doi:10.1016/j.applthermaleng.2011.12.040

Anderson, T., Barak, P., Davidson, C., 2014. A Greenhouse Study Comparing Brushite, MAP , DAP , TSP , and Struvite Using a Phosphorus-Deficient Prairie Soil, in: ASA, CSSA, \& SSSA International Annual Meeting Nov. 2-5 2014. ASA, CSSA, \& SSSA, Long Beach, CA, pp. 446-9.

Atienza-Martínez, M., Gea, G., Arauzo, J., Kersten, S.R.A., Kootstra, A.M.J., 2014. Phosphorus recovery from sewage sludge char ash. Biomass Bioeng. 65, 42-50. doi:10.1016/j.biombioe.2014.03.058

Beck, J., Brandenstein, J., Unterberger, S., Hein, K.R.G., 2004. Effects of sewage sludge and meat and bone meal Co-combustion on SCR catalysts. Appl. Catal. B Environ. 49, 15-25. doi:10.1016/j.apcatb.2003.11.007

Benzing, P., Richardson, C.J., 2005. $\mathrm{CaCO} 3$ causes underestimation of $\mathrm{NaOH}$ extractable phosphorus in sequential fractionations. Soil Sci. 170, 802-809. doi:10.1097/01.ss.0000190501.98437.d1

Cao, Y., Pawłowski, A., 2012. Sewage sludge-to-energy approaches based on anaerobic digestion and pyrolysis: Brief overview and energy efficiency assessment. Renew. Sustain. Energy Rev. 16, 16571665. doi:10.1016/j.rser.2011.12.014

Choban, A., Winkler, I., 2008. Removal of highly toxic wastewater pollutants with excessive active sludge, in: Václavíková, M., Vitale, K., Gallios, G.P., Ivaničová, L. (Eds.), Water Treatment Technologies for the Removal of High-Toxicity Pollutants. Springer, Dordrecht, pp. 219-223. 
Donatello, S., Cheeseman, C.R., 2013. Recycling and recovery routes for incinerated sewage sludge ash (ISSA): A review. Waste Manag. 33, 2328-2340. doi:10.1016/j.wasman.2013.05.024

Elert, G., 2016. Chemical Potential Energy [WWW Document]. Phys. Hypertextb. URL http://physics.info/energy-chemical/ (accessed 10.19.16).

Frandsen, F.J., Dam-Johansen, K., Rasmussen, P., 1994. Trace elements from combustion and gasification of coal-An equilibrium approach. Prog. Energy Combust. Sci. 20, 115-138.

Franz, M., 2008. Phosphate fertilizer from sewage sludge ash (SSA). Waste Manag. 28, 1809-1818. doi:10.1016/j.wasman.2007.08.011

Fraser, J.L., Lum, K.R., 1983. Availability of elements of environmental importance in incinerated sludge ash. Environ. Sci. Technol. 17, 52-54. doi:10.1021/es00107a013

Fytili, D., Zabaniotou, A., 2008. Utilization of sewage sludge in EU application of old and new methods-A review. Renew. Sustain. Energy Rev. 12, 116-140. doi:10.1016/j.rser.2006.05.014

Hansen, T.H., Laursen, K.H., Persson, D.P., Pedas, P., Husted, S., Schjoerring, J.K., 2009. Micro-scaled highthroughput digestion of plant tissue samples for multi-elemental analysis. Plant Methods 5, 1-11.

Hansen, V., Müller-Stöver, D., Ahrenfeldt, J., Holm, J.K., Henriksen, U.B., Hauggaard-Nielsen, H., 2015. Gasification biochar as a valuable by-product for carbon sequestration and soil amendment. Biomass Bioeng. 72, 300-308. doi:10.1016/j.biombioe.2014.10.013

Henriksen, U., Ahrenfeldt, J., Jensen, T.K., Gøbel, B., Bentzen, J.D., Hindsgaul, C., Sørensen, L.H., 2006. The design, construction and operation of a 75kW two-stage gasifier. Energy 31, 1542-1553. doi:10.1016/j.energy.2005.05.031

Henze, M., 2006. Teoretisk spildevandsrensning, Biologiske og kemiske processer (Eng.: Theoretical Wastewater Treatment, Biological and Chemical Processes), 3rd ed. Polyteknisk Forlag, Lyngby.

Huang, X., Chen, Y., Shenker, M., 2007. Solid Phosphorus Phase in Aluminum- and Iron-Treated Biosolids. J. Environ. Qual. 36, 549-556. doi:10.2134/jeq2006.0155

Hukari, S., Hermann, L., Nättorp, A., 2016. From wastewater to fertilisers - Technical overview and critical review of European legislation governing phosphorus recycling. Sci. Total Environ. 542, 1127-1135. doi:10.1016/j.scitotenv.2015.09.064

Igos, E., Benetto, E., Venditti, S., Kohler, C., Cornelissen, A., Moeller, R., Biwer, A., 2012. Is it better to remove pharmaceuticals in decentralized or conventional wastewater treatment plants? A life cycle assessment comparison. Sci. Total Environ. 438, 533-40. doi:10.1016/j.scitotenv.2012.08.096

Jakobsen, P., Willett, I.R., 1986. Comparisons of the fertilizing and liming properties of lime-treated sewage sludge with its incinerated ash. Fertil. Res. 9, 187-197. doi:10.1007/BF01050345

Judex, J.W., Gaiffi, M., Burgbacher, H.C., 2012. Gasification of dried sewage sludge: Status of the demonstration and the pilot plant. Waste Manag. 32, 719-723. doi:10.1016/j.wasman.2011.12.023

Kahiluoto, H., Kuisma, M., Ketoja, E., Salo, T., Heikkinen, J., 2015. Phosphorus in Manure and Sewage Sludge More Recyclable than in Soluble Inorganic Fertilizer. Environ. Sci. Technol. 49, 2115-2122. doi:10.1021/es503387y

Kelessidis, A., Stasinakis, A.S., 2012. Comparative study of the methods used for treatment and final 
disposal of sewage sludge in European countries. Waste Manag. 32, 1186-1195.

doi:10.1016/j.wasman.2012.01.012

Krogstad, T., Sogn, T.A., Asdal, Å., Sæbø, A., 2005. Influence of chemically and biologically stabilized sewage sludge on plant-available phosphorous in soil. Ecol. Eng. 25, 51-60. doi:10.1016/j.ecoleng.2005.02.009

Krüger, 2009. BioCon Sludge Drying Solutions [WWW Document]. Prod. sheet. URL http://www.kruger.dk/krugeras/ressources/documents/2/2876,BioCon_08_web.pdf (accessed 10.18.16).

Krüger, O., Grabner, A., Adam, C., 2014. Complete Survey of German Sewage Sludge Ash. Environ. Sci. Technol. 48, 11811-11818.

Kuligowski, K., Poulsen, T.G., Stoholm, P., Pind, N., Laursen, J., 2008. Nutrients and heavy metals distribution in thermally treated pig manure. Waste Manag. Res. 26, 347-354. doi:10.1177/0734242X08090075

Linderholm, K., Tillman, A., Erik, J., 2012. Life cycle assessment of phosphorus alternatives for Swedish agriculture. Resour. Conserv. Recycl. 66, 27-39. doi:10.1016/j.resconrec.2012.04.006

Lukkari, K., Hartikainen, H., Leivuori, M., 2007. Fractionation of sediment phosphorus revisited: I Fractionation steps and their biogeochemical basis. Limnol. Oceanogr. Methods 5, 433-444. doi:10.4319/lom.2007.5.433

Manara, P., Zabaniotou, A., 2012. Towards sewage sludge based biofuels via thermochemical conversion - A review. Renew. Sustain. Energy Rev. 16, 2566-2582. doi:10.1016/j.rser.2012.01.074

Matinde, E., Sasaki, Y., Hino, M., 2008. Phosphorus Gasification from Sewage Sludge during Carbothermic Reduction. ISIJ Int. 48, 912-917. doi:10.2355/isijinternational.48.912

Mattenberger, H., Fraissler, G., Brunner, T., Herk, P., Hermann, L., Obernberger, I., 2008. Sewage sludge ash to phosphorus fertiliser: Variables influencing heavy metal removal during thermochemical treatment. Waste Manag. 28, 2709-2722. doi:10.1016/j.wasman.2008.01.005

Michael, I., Rizzo, L., McArdell, C.S., Manaia, C.M., Merlin, C., Schwartz, T., Dagot, C., Fatta-Kassinos, D., 2013. Urban wastewater treatment plants as hotspots for the release of antibiotics in the environment: a review. Water Res. 47, 957-95. doi:10.1016/j.watres.2012.11.027

Moir, J.O., Tiessen, H., 2007. Characterization of Available P by Sequential Extraction, in: Carter, M.R., Gregorich, E.G. (Eds.), Soil Sampling and Methods of Analysis. CRC Press. doi:10.1201/9781420005271.ch25

Mun, T.Y., Kim, J.W., Kim, J.S., 2013. Air gasification of dried sewage sludge in a two-stage gasifier: Part 1. the effects and reusability of additives on the removal of tar and hydrogen production. Int. J. Hydrogen Energy 38, 5226-5234. doi:10.1016/j.ijhydene.2012.10.120

Nakakubo, T., Tokai, A., Ohno, K., 2012. Comparative assessment of technological systems for recycling sludge and food waste aimed at greenhouse gas emissions reduction and phosphorus recovery. J. Clean. Prod. 32, 157-172. doi:10.1016/j.jclepro.2012.03.026

Nanzer, S., Oberson, A., Berger, L., Berset, E., Hermann, L., Frossard, E., 2014. The plant availability of phosphorus from thermo-chemically treated sewage sludge ashes as studied by 33P labeling techniques. Plant Soil 377, 439-456. doi:10.1007/s11104-013-1968-6 
Narayan, V., Jensen, P.A., Henriksen, U.B., Glarborg, P., Lin, W., Nielsen, R.G., 2016. Defluidization in fluidized bed gasifiers using high-alkali content fuels. Biomass Bioeng. 91, 160-174.

doi:10.1016/j.biombioe.2016.05.009

Nguyen, T.L.T., Hermansen, J.E., Nielsen, R.G., 2013. Environmental assessment of gasification technology for biomass conversion to energy in comparison with other alternatives: the case of wheat straw. J. Clean. Prod. 53, 138-148. doi:10.1016/j.jclepro.2013.04.004

Nielsen, R.G., 2007. Optimering af Lav Temperatur Cirkulerende Fluid Bed forgasningsprocessen til biomasse med højt askeindhold (Eng.: Optimizing Low Temperature Circulating Fluidized Bed gasification for high alkali biomass). Technical University of Denmark, Lyngby, Denmark.

Nzihou, A., Stanmore, B., 2013. The fate of heavy metals during combustion and gasification of contaminated biomass-A brief review. J. Hazard. Mater. 256-257, 56-66.

doi:10.1016/j.jhazmat.2013.02.050

Ottosen, L.M., Jensen, P.E., Kirkelund, G.M., 2016. Phosphorous recovery from sewage sludge ash suspended in water in a two-compartment electrodialytic cell. Waste Manag. 51, 142-148. doi:10.1016/j.wasman.2016.02.015

Ottosen, L.M., Kirkelund, G.M., Jensen, P.E., 2013. Extracting phosphorous from incinerated sewage sludge ash rich in iron or aluminum. Chemosphere 91, 963-969. doi:10.1016/j.chemosphere.2013.01.101

P. Viader, R., E. Jensen, P., M. Ottosen, L., P. Thomsen, T., Ahrenfeldt, J., Hauggaard-Nielsen, H., 2016. Comparison of phosphorus recovery from incineration and gasification sewage sludge ash, in: Abstract from 2nd IWA Conference on Holistic Sludge Management (HSM2016), Malmö, Sweden.

Parés Viader, R., Jensen, P.E., Ottosen, L.M., Ahrenfeldt, J., Hauggaard-Nielsen, H., 2015. Electrodialytic extraction of phosphorus from ash of low-temperature gasification of sewage sludge. Electrochim. Acta In Press. doi:10.1016/j.electacta.2015.05.025

Prisum, J.M., 1999. Danmarks første fluid-bed forbrændingsanlæg (Eng.: Denmark's first fluid bed incineration plant). Stads- og Havneingeniøren 90, 39-41.

Qian, T., Jiang, H., 2014. Migration of Phosphorus in Sewage Sludge during Different Thermal Treatment Processes. Sustain. Chem. Eng. 2, 1411-1419.

Richardson, A.E., Lynch, J.P., Ryan, P.R., Delhaize, E., Smith, F.A., Smith, S.E., Harvey, P.R., Ryan, M.H., Veneklaas, E.J., Lambers, H., Oberson, A., Culvenor, R. a., Simpson, R.J., 2011. Plant and microbial strategies to improve the phosphorus efficiency of agriculture. Plant Soil 349, 121-156. doi:10.1007/s11104-011-0950-4

Roberts, T.L., 2014. Cadmium and Phosphorous Fertilizers: The Issues and the Science. Procedia Eng. 83, 52-59. doi:http://dx.doi.org/10.1016/j.proeng.2014.09.012

Samolada, M.C., Zabaniotou, A.A., 2014. Comparative assessment of municipal sewage sludge incineration, gasification and pyrolysis for a sustainable sludge-to-energy management in Greece. Waste Manag. 34, 411-420. doi:10.1016/j.wasman.2013.11.003

Singh, R.P., Agrawal, M., 2008. Potential benefits and risks of land application of sewage sludge. Waste Manag. 28, 347-358. doi:10.1016/j.wasman.2006.12.010

Soria, J., Gauthier, D., Falcoz, Q., Flamant, G., Mazza, G., 2013. Local CFD kinetic model of cadmium 
vaporization during fluid bed incineration of municipal solid waste. J. Hazard. Mater. 248-249, 276284. doi:10.1016/j.jhazmat.2013.01.015

Stoholm, P., Nielsen, R.G., Nielsen, M.B., Sander, B., Nørholm, N., Krogh, J., Henriksen, U.B., Qvale, B., 2007. LT-CFB forgasser $500 \mathrm{~kW}$ fors $\varnothing \mathrm{g}$ m.v. Slutrapport (Eng.: LT-CFB gasifier $500 \mathrm{~kW}$ experiment and more. Final report) (No. 4833). DFBT, Anhydro, FORCE Technology, Elsam Engineering, DTU MEK, Denmark.

Suciu, N.A., Lamastra, L., Trevisan, M., 2015. PAHs content of sewage sludge in Europe and its use as soil fertilizer. Waste Manag. 41, 119-127. doi:10.1016/j.wasman.2015.03.018

Thomsen, T.P., Ravenni, G., Holm, J.K., Ahrenfeldt, J., Hauggaard-Nielsen, H., Henriksen, U.B., 2015. Screening of various low-grade biomass materials for low temperature gasification: Method development and application. Biomass Bioeng. 79, 128-144. doi:10.1016/j.biombioe.2014.12.019

Vogel, C., Exner, R.M., Adam, C., 2013. Heavy metal removal from sewage sludge ash by thermochemical treatment with polyvinylchloride. Environ. Sci. Technol. 47, 563-567. doi:10.1021/es300610e

Wang, C., Zhang, Y., Li, H., Morrison, R.J., 2013. Sequential extraction procedures for the determination of phosphorus forms in sediment. Limnology 14, 147-157. doi:10.1007/s10201-012-0397-1

Werle, S., 2015. Gasification of a Dried Sewage Sludge in a Laboratory Scale Fixed Bed Reactor. Energies 8, 8562-8572. doi:10.3390/en8088562

Xu, H., He, P., Gu, W., Wang, G., Shao, L., 2012. Recovery of phosphorus as struvite from sewage sludge ash. J. Environ. Sci. (China) 24, 1533-1538. doi:10.1016/S1001-0742(11)60969-8

Zhang, Y., Chen, Y., Meng, A., Li, Q., Cheng, H., 2008. Experimental and thermodynamic investigation on transfer of cadmium influenced by sulfur and chlorine during municipal solid waste (MSW) incineration. J. Hazard. Mater. 153, 309-319. doi:10.1016/j.jhazmat.2007.08.054

Zhang, Y., Li, Q., Meng, A., Chen, Y., Zhou, Y., Chen, C., 2007. Effects of Sulfur Compounds on Cd Partitioning in a Simulated Municipal Solid Waste Incinerator. Chinese J. Chem. Eng. 15, 889-894.

Zwart, R., Heijden, S. Van Der, Emmen, R., Dall, J., Stoholm, P., Krogh, J., 2010. Tar removal from lowtemperature gasifiers (No. ECN-E--10-008). ECN, Dall Energy, DTU, DFBT, Dahlman \& Anhydro, The Netherlands.

\section{Supplementary Information}

SI Table 1: Results from sequential extraction of CPSE substrates.

\begin{tabular}{|c|c|c|c|c|c|c|c|c|c|}
\hline & & $\begin{array}{c}\mathrm{Al} \\
(\mathrm{mol} / \mathrm{kg})\end{array}$ & $\begin{array}{c}\mathrm{Ca} \\
(\mathrm{mol} / \mathrm{kg})\end{array}$ & $\begin{array}{c}\mathrm{Fe} \\
(\mathrm{mol} / \mathrm{kg})\end{array}$ & $\begin{array}{c}\mathrm{K} \\
(\mathrm{mol} / \mathrm{kg})\end{array}$ & $\begin{array}{c}\mathrm{Mg} \\
(\mathrm{mol} / \mathrm{kg})\end{array}$ & $\begin{array}{c}\mathrm{Na}^{\mathrm{b}} \\
(\mathrm{mol} / \mathrm{kg})\end{array}$ & $\begin{array}{c}\mathrm{P} \\
(\mathrm{mol} / \mathrm{kg})\end{array}$ & $\begin{array}{c}\mathrm{S} \\
(\mathrm{mol} / \mathrm{kg})\end{array}$ \\
\hline \multirow{6}{*}{ Sludge } & $\mathrm{H}_{2} \mathrm{O}$ & 0.001 & 0.049 & 0.002 & 0.024 & 0.040 & 0.023 & 0.039 & 0.067 \\
\hline & $\mathrm{C}_{2} \mathrm{H}_{3} \mathrm{O}_{2} \mathrm{NH}_{4}$ & 0.002 & 0.768 & 0.001 & 0.017 & 0.105 & 0.007 & 0.112 & 0.013 \\
\hline & $\mathrm{NaHCO}_{3}$ & 0.000 & 0.026 & 0.002 & 0.006 & 0.008 & & 0.117 & 0.013 \\
\hline & $\mathrm{NaOH}$ & 0.484 & 0.008 & 0.010 & 0.003 & 0.001 & & 0.604 & 0.059 \\
\hline & $\mathrm{HCl}$ & 0.190 & 0.343 & 0.349 & 0.007 & 0.047 & & 0.392 & 0.009 \\
\hline & Residuals $^{\mathrm{a}}$ & 0.129 & 0.130 & 0.080 & 0.075 & 0.036 & & -0.003 & 0.055 \\
\hline \multirow{3}{*}{ Pyr } & $\mathrm{H}_{2} \mathrm{O}$ & 0.018 & 0.033 & 0.000 & 0.008 & 0.006 & 0.009 & 0.001 & 0.028 \\
\hline & $\mathrm{C}_{2} \mathrm{H}_{3} \mathrm{O}_{2} \mathrm{NH}_{4}$ & 0.002 & 0.686 & 0.000 & 0.013 & 0.073 & 0.008 & 0.089 & 0.007 \\
\hline & $\mathrm{NaHCO}_{3}$ & 0.000 & 0.031 & 0.002 & 0.012 & 0.010 & & 0.081 & 0.004 \\
\hline
\end{tabular}




\begin{tabular}{|c|c|c|c|c|c|c|c|c|c|}
\hline & $\mathrm{NaOH}$ & 0.551 & 0.002 & 0.000 & 0.018 & 0.000 & & 0.571 & 0.027 \\
\hline & $\mathrm{HCl}$ & 0.672 & 1.114 & 0.621 & 0.050 & 0.223 & & 1.499 & 0.011 \\
\hline & Residuals $^{a}$ & 0.439 & 0.677 & 0.332 & 0.183 & 0.211 & & 0.464 & 0.179 \\
\hline \multirow{6}{*}{ Pyr OX } & $\mathrm{H}_{2} \mathrm{O}$ & 0.001 & 0.123 & 0.000 & 0.014 & 0.027 & 0.012 & 0.001 & 0.156 \\
\hline & $\mathrm{C}_{2} \mathrm{H}_{3} \mathrm{O}_{2} \mathrm{NH}_{4}$ & 0.001 & 0.834 & 0.000 & 0.028 & 0.122 & 0.015 & 0.193 & 0.034 \\
\hline & $\mathrm{NaHCO}_{3}$ & 0.000 & 0.022 & 0.001 & 0.016 & 0.011 & & 0.141 & 0.007 \\
\hline & $\mathrm{NaOH}$ & 0.850 & 0.003 & 0.000 & 0.018 & 0.001 & & 0.891 & 0.007 \\
\hline & $\mathrm{HCl}$ & 0.833 & 1.629 & 0.510 & 0.059 & 0.235 & & 1.915 & 0.023 \\
\hline & Residuals $^{a}$ & 0.813 & 0.578 & 0.890 & 0.206 & 0.253 & & -0.221 & 0.043 \\
\hline \multirow{6}{*}{ LT-CFB } & $\mathrm{H}_{2} \mathrm{O}$ & 0.020 & 0.026 & 0.000 & 0.015 & 0.005 & 0.010 & 0.001 & 0.047 \\
\hline & $\mathrm{C}_{2} \mathrm{H}_{3} \mathrm{O}_{2} \mathrm{NH}_{4}$ & 0.014 & 0.204 & 0.003 & 0.013 & 0.041 & 0.006 & 0.010 & 0.008 \\
\hline & $\mathrm{NaHCO}_{3}$ & 0.000 & 0.011 & 0.002 & 0.007 & 0.006 & & 0.026 & 0.004 \\
\hline & $\mathrm{NaOH}$ & 0.393 & 0.001 & 0.000 & 0.018 & 0.000 & & 0.480 & 0.039 \\
\hline & $\mathrm{HCl}$ & 0.767 & 2.152 & 0.781 & 0.060 & 0.384 & & 2.513 & 0.012 \\
\hline & Residuals $^{\mathrm{a}}$ & 0.957 & 0.850 & 0.482 & 0.290 & 0.247 & & 0.505 & 0.190 \\
\hline \multirow{6}{*}{$\begin{array}{l}\text { LT-CFB } \\
\text { OX }\end{array}$} & $\mathrm{H}_{2} \mathrm{O}$ & 0.001 & 0.145 & 0.000 & 0.018 & 0.025 & 0.015 & 0.004 & 0.205 \\
\hline & $\mathrm{C}_{2} \mathrm{H}_{3} \mathrm{O}_{2} \mathrm{NH}_{4}$ & 0.002 & 0.186 & 0.000 & 0.018 & 0.110 & 0.007 & 0.123 & 0.019 \\
\hline & $\mathrm{NaHCO}_{3}$ & 0.001 & 0.013 & 0.001 & 0.010 & 0.013 & & 0.059 & 0.003 \\
\hline & $\mathrm{NaOH}$ & 0.587 & 0.001 & 0.000 & 0.015 & 0.000 & & 0.648 & 0.003 \\
\hline & $\mathrm{HCl}$ & 0.625 & 2.296 & 0.325 & 0.085 & 0.240 & & 2.482 & 0.026 \\
\hline & Residuals ${ }^{a}$ & 1.440 & 0.755 & 1.128 & 0.252 & 0.305 & & -0.241 & -0.015 \\
\hline \multirow{6}{*}{$\begin{array}{l}\text { Two- } \\
\text { Stage }\end{array}$} & $\mathrm{H}_{2} \mathrm{O}$ & 0.004 & 0.006 & 0.000 & 0.006 & 0.003 & 0.006 & 0.006 & 0.005 \\
\hline & $\mathrm{C}_{2} \mathrm{H}_{3} \mathrm{O}_{2} \mathrm{NH}_{4}$ & 0.001 & 0.171 & 0.000 & 0.006 & 0.093 & 0.004 & 0.095 & 0.002 \\
\hline & $\mathrm{NaHCO}_{3}$ & 0.000 & 0.009 & 0.002 & 0.004 & 0.011 & & 0.051 & 0.001 \\
\hline & $\mathrm{NaOH}$ & 0.084 & 0.002 & 0.000 & 0.015 & 0.000 & & 0.310 & 0.009 \\
\hline & $\mathrm{HCl}$ & 0.629 & 2.431 & 0.777 & 0.056 & 0.293 & & 2.367 & 0.003 \\
\hline & Residuals $^{a}$ & 1.428 & 0.654 & 0.560 & 0.296 & 0.303 & & 0.769 & 0.075 \\
\hline \multirow{6}{*}{$\begin{array}{l}\text { Two- } \\
\text { Stage } \\
\text { OX }\end{array}$} & $\mathrm{H}_{2} \mathrm{O}$ & 0.000 & 0.020 & 0.000 & 0.007 & 0.008 & 0.006 & 0.006 & 0.041 \\
\hline & $\mathrm{C}_{2} \mathrm{H}_{3} \mathrm{O}_{2} \mathrm{NH}_{4}$ & 0.001 & 0.200 & 0.000 & 0.008 & 0.205 & 0.004 & 0.248 & 0.002 \\
\hline & $\mathrm{NaHCO}_{3}$ & 0.000 & 0.016 & 0.001 & 0.005 & 0.024 & & 0.060 & 0.000 \\
\hline & $\mathrm{NaOH}$ & 0.423 & 0.001 & 0.000 & 0.011 & 0.000 & & 0.508 & 0.001 \\
\hline & $\mathrm{HCl}$ & 0.579 & 2.217 & 0.186 & 0.062 & 0.179 & & 1.913 & 0.004 \\
\hline & Residuals $^{a}$ & 1.713 & 1.030 & 1.337 & 0.299 & 0.294 & & 0.440 & 0.005 \\
\hline \multirow{6}{*}{$\begin{array}{l}\text { Two- } \\
\text { Stage } \\
\text { OX2 }\end{array}$} & $\mathrm{H}_{2} \mathrm{O}$ & 0.000 & 0.028 & 0.000 & 0.004 & 0.008 & 0.004 & 0.006 & 0.043 \\
\hline & $\mathrm{C}_{2} \mathrm{H}_{3} \mathrm{O}_{2} \mathrm{NH}_{4}$ & 0.001 & 0.211 & 0.000 & 0.008 & 0.240 & 0.005 & 0.286 & 0.002 \\
\hline & $\mathrm{NaHCO}_{3}$ & 0.000 & 0.011 & 0.001 & 0.005 & 0.019 & & 0.060 & 0.000 \\
\hline & $\mathrm{NaOH}$ & 0.474 & 0.001 & 0.000 & 0.010 & 0.000 & & 0.568 & 0.001 \\
\hline & $\mathrm{HCl}$ & 0.679 & 2.508 & 0.197 & 0.055 & 0.172 & & 2.300 & 0.008 \\
\hline & Residuals $^{a}$ & 1.583 & 0.716 & 1.369 & 0.309 & 0.258 & & -0.044 & 0.012 \\
\hline \multirow{6}{*}{$\begin{array}{l}\text { Fixed } \\
\text { bed } \\
\text { incine- } \\
\text { ration }\end{array}$} & $\mathrm{H}_{2} \mathrm{O}$ & 0.001 & 0.108 & 0.000 & 0.008 & 0.018 & 0.010 & 0.005 & 0.149 \\
\hline & $\mathrm{C}_{2} \mathrm{H}_{3} \mathrm{O}_{2} \mathrm{NH}_{4}$ & 0.003 & 0.185 & 0.000 & 0.011 & 0.083 & 0.006 & 0.115 & 0.016 \\
\hline & $\mathrm{NaHCO}_{3}$ & 0.001 & 0.011 & 0.001 & 0.007 & 0.010 & & 0.063 & 0.003 \\
\hline & $\mathrm{NaOH}$ & 0.713 & 0.001 & 0.000 & 0.016 & 0.000 & & 0.740 & 0.002 \\
\hline & $\mathrm{HCl}$ & 0.510 & 2.301 & 0.088 & 0.079 & 0.258 & & 2.229 & 0.077 \\
\hline & Residuals $^{\mathrm{a}}$ & 1.547 & 0.828 & 1.437 & 0.258 & 0.343 & & 0.028 & 0.003 \\
\hline \multirow{6}{*}{$\begin{array}{l}\text { Fluid } \\
\text { bed } \\
\text { incine- } \\
\text { ration }\end{array}$} & $\mathrm{H}_{2} \mathrm{O}$ & 0.005 & 0.186 & 0.000 & 0.006 & 0.015 & 0.016 & 0.000 & 0.216 \\
\hline & $\mathrm{C}_{2} \mathrm{H}_{3} \mathrm{O}_{2} \mathrm{NH}_{4}$ & 0.003 & 0.231 & 0.000 & 0.008 & 0.090 & 0.008 & 0.124 & 0.037 \\
\hline & $\mathrm{NaHCO}_{3}$ & 0.001 & 0.019 & 0.003 & 0.005 & 0.010 & & 0.045 & 0.005 \\
\hline & $\mathrm{NaOH}$ & 0.259 & 0.003 & 0.001 & 0.017 & 0.000 & & 0.289 & 0.003 \\
\hline & $\mathrm{HCl}$ & 0.272 & 2.133 & 0.265 & 0.066 & 0.218 & & 2.099 & 0.007 \\
\hline & Residuals $^{a}$ & 1.066 & 1.008 & 1.374 & 0.283 & 0.328 & & 0.761 & 0.052 \\
\hline
\end{tabular}



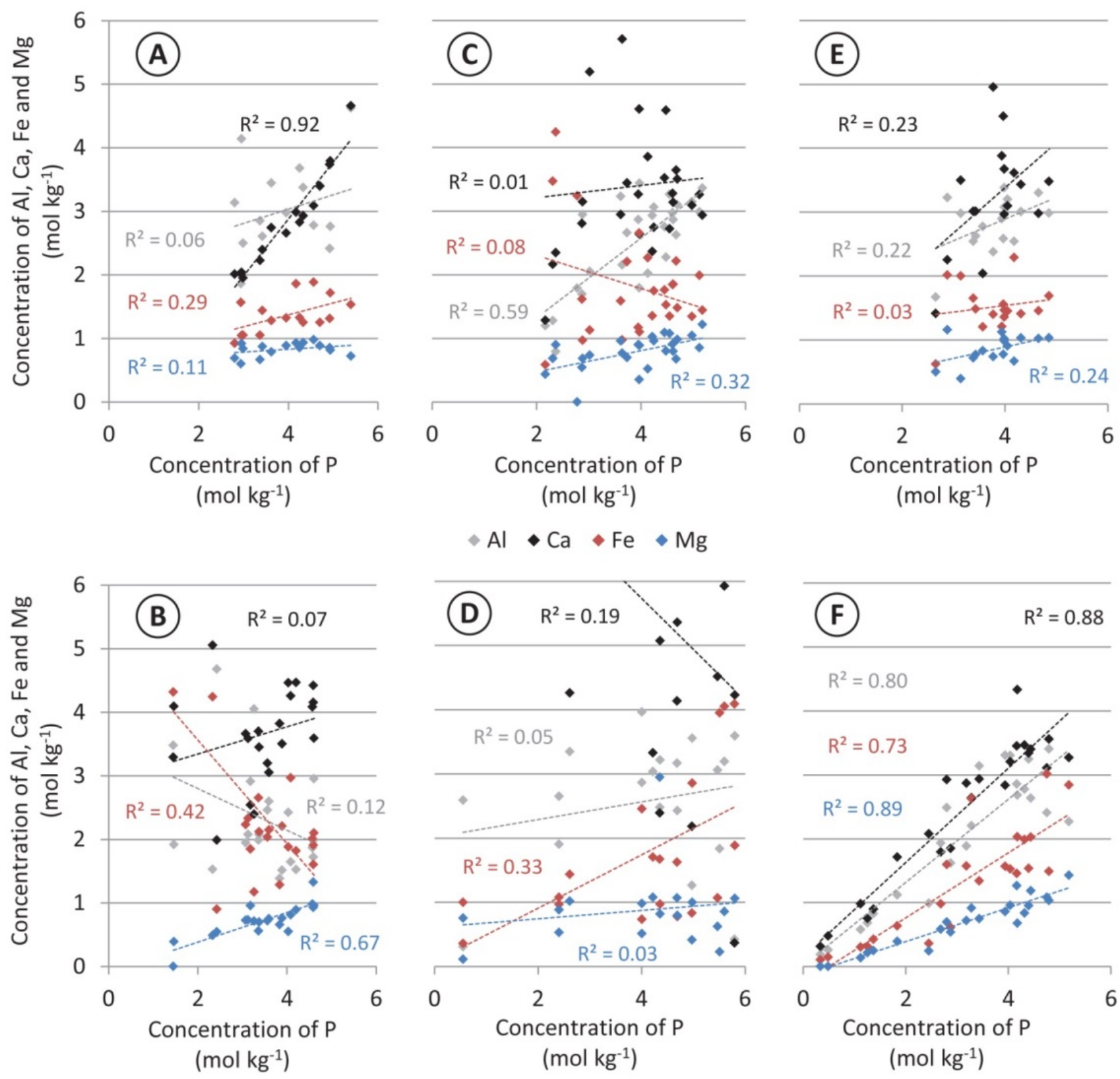

SI Figure 1: SEM-EDS point analysis. A) Dry sludge B) Fluid bed incineration ash C) Slow pyrolysis char D) Oxidized slow pyrolysis char E) LT-CFB ash F) Oxidized LT-CFB ash 